Canadian

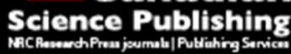

Canadian Geotechnical Journal

Revue canadienne de géotechnique

\title{
A UNIFYING FRAMEWORK FOR MODELING SWELLING SOIL BEHAVIOUR
}

\begin{tabular}{|r|l|}
\hline Journal: & Canadian Geotechnical Journal \\
\hline Manuscript ID & cgj-2015-0049.R3 \\
\hline Manuscript Type: & Article \\
\hline Date Submitted by the Author: & 11 -May-2016 \\
\hline Complete List of Authors: & $\begin{array}{l}\text { Lim, Bee Fong; Royal Military College of Canada, Civil Engineering } \\
\text { Siemens, Gregory; GeoEngineering Centre at Queens-RMC, }\end{array}$ \\
\hline Keyword: & expansive soil, experimental, unifying framework, unsaturated soil \\
\hline & \\
\hline
\end{tabular}




\title{
A UNIFYING FRAMEWORK FOR MODELING SWELLING SOIL BEHAVIOUR
}

\author{
B.F. Lim \\ GeoEngineering Centre at Queen's-RMC, Department of Civil Engineering, \\ Royal Military College of Canada, Kingston, Ontario, CANADA
}

G.A. Siemens (Corresponding Author)

Professor, GeoEngineering Centre at Queen's-RMC, Room S3418 Sawyer Building,

15 General Crerar, Department of Civil Engineering, Royal Military College of Canada, Kingston,

Ontario, CANADA, K7K 7B4, t: 613-541-6000 x6396, f: 613-541-6218, e: siemens@rmc.ca

Words: $\quad 8400$

Tables: $\quad 5$

Figures: $\quad 14$

\section{ABSTRACT}

The destructive effect of expansive soils on infrastructure is one of the classical issues associated with unsaturated soils. Given the continuing challenges associated with swelling soils there is still a need for a practical analysis method. The Swelling Equilibrium Limit (SEL) provides a concept for modeling expansive soil behaviour. The SEL is an upper bound swelling limit, which depends on the soil's initial state and the boundary conditions upon wetting. The SEL is obtained experimentally from swelling tests performed by applying a range of swelling scenarios from rigid boundary condition to free swelling without confinement. In this paper, improvements to the triaxial swelling apparatus are reported, SELs for two new swelling soils are characterized, and a framework for SEL prediction is developed. The SEL framework is developed to relate SEL parameters to index properties as well as the soil's initial volume. SEL parameters are correlated to liquid limit, plasticity index, free swell potential, and specific volume. The relationships are used to estimate the SEL for Regina clay, which is shown to agree with experimental data.

Keywords: expansive soil, experimental, unifying framework, unsaturated soil 


\section{INTRODUCTION}

Swelling-induced damage to infrastructure costs billions of dollars annually. On the positive side, applications such as landfills rely on the same swelling potential to create self-healing environmental barriers. Significant research is focused on challenges associated with swelling soils (Komine and Ogata 1994; 2004; Miller et al. 1995; Yilmaz 2006; Nagaraj et al. 2009; Puppala and Cerato 2009; Siemens and Blatz 2009; Houston et al. 2011; Kayabali and Demir 2011; Rao et al. 2011; Kodikara 2012; Powell et al. 2013). Vanapalli and Lu (2012) identified twenty-five different methods for heave prediction grouping them into empirical, oedometer, and suction methods. As challenges associated with swelling soils are still being encountered and the swelling potential is required for environmental barriers, a unifying framework for swelling behaviour is a valuable tool for practitioners and researchers. Ideally a unifying framework would link experimental results to a practical numerical modeling tool.

Much effort has been invested in development of advanced laboratory testing for swelling soils (ASTM D4546; Wiebe et al. 1998; Yong 1999; Al-Shamrani and Al-Mhaidib 2000; Aversa and Nicotera 2002; Sánchez et al. 2008; Wang et al. 2012; Cui et al. 2014; Liu et al. 2014). Typically, swelling tests are conducted in one-dimensional oedometer apparatuses (ASTM D4546) where a discshape specimen is placed inside a rigid ring. The specimen is given access to water to activate swelling. Expansion or swelling-induced pressure is measured with a displacement sensor or a loading frame (Ferber et al. 2009; Baille et al. 2010; Mohajerani et al. 2011; Powell et al. 2012a; Powell et al. 2012b; Abbas et al. 2015). One of the drawbacks of oedometric apparatuses is the rigid lateral constraint imposed on the soil specimen (Al-Shamrani and Al-Mhaidib 2000). The rigid boundary condition confines the specimen to deform only in vertical direction, which may or may not be representative of field applications. Al-Shamrani and Dhowian (2003) concluded that oedometer test overestimated measured field data but a triaxial swelling test gave better prediction. Swelling soil testing in a triaxial Lim and Siemens, 2016 Page 2 of 26 
Submitted to Canadian Geotechnical Journal as an Article \#cgj-2015-0049

May 2016

apparatus has the advantages of allowing more generalized conditions and direct measurement of state variables (Al-Mhaidib 1998; Al-Shamrani and Al-Mhaidib 2000; Al-Shamrani and Dhowian 2003). Siemens and Blatz (2007) reported a new triaxial swelling test that included the capacity to automatically apply boundary conditions as well as allow for suction measurement (Wheeler and Sivakumar 1995; Rampino et al. 1999; Sivakumar and Wheeler 2000; Lloret et al. 2003; Sun et al. 2007).

Adem and Vanapalli (2015) reviewed the methods for modeling expansive soils and divided models into three categories: consolidation theory-based methods, water content-based methods, and suction-based methods. Modeling analysis contributes to the applicability and practicality of advanced analysis methods for use in practical engineering problems (Fredlund 1983; Rees and Thomas 1993; Miller et al. 1995; Briaud et al. 2003; Masia et al. 2004; Ito and Hu 2011; Puppala et al. 2014). Puppala et al. (2014) developed a model that is based on seasonal moisture content to predict swelling and shrinkage deformations. Constitutive models have also been developed that capture swelling soil behaviour while only requiring nominally more parameters compared with other advanced constitutive models (Shuai and Fredlund 1998; Sheng et al. 2008).

A common approach to interpreting general trends in experimental results and constitutive models is to relate engineering parameters to basic soil properties. For example, Nagaraj and Srinivasa Murthy (1986) and Burland (1990) related soil compressibility to index properties, thus allowing for interpretation of soil structure. Additionally, swelling potential has been related successfully to the soil index properties (Shi et al. 2002; Komine and Ogata 2003; Prakash and Sridharan 2004; Rao et al. 2004; Ito and Azam, 2010; Cui et al. 2012; Ito and Azam 2013). Swelling potential is generally related to the volume state ( specific volume, void ratio, $\mathrm{V}=\mathrm{e}+1$ ), liquid limit, plasticity index, and free swell potential.

Despite much effort to characterize swelling soil behaviour, general agreement on a practical analysis tool for use by researchers and practitioners has not been found. Siemens and Blatz (2009) 
Submitted to Canadian Geotechnical Journal as an Article \#cgj-2015-0049

May 2016

proposed a concept, known as the Swell Equilibrium Limit (SEL). The underlying notion is that expansive soils have a swelling potential that is realized as expansion or swelling-induced stresses. How the swelling potential is realized depends on the mechanical boundary conditions, which range from constant stress to constant volume. An application to illustrate the SEL is a retaining wall constructed using swelling soil that is subjected to infiltration conditions (Figure 1). Three conditions are highlighted on the retaining wall and their stress-volume paths are plotted in specific volume-mean stress (V-p) space. Swelling potential is activated by water infiltration. Near the surface (soil element 1), unconfined swelling conditions prevail as the soil element is at shallow depth. On the plot (Figure 1b), the stressvolume path starts at zero stress at the initial specific volume and proceeds vertically until the swelling potential is satisfied. The second condition (soil element 2) is swelling at depth under a constant mean stress (CMS) equal to the stress from the retaining wall and overlying soil. In V-p space (Figure 1b), the soil element is initially at a stress associated with its overburden and then swells upwardly along a vertical stress-volume path until its swelling potential is satisfied. Under CMS conditions, no additional confinement is provided during swelling. The elevated initial stress along with the CMS boundary causes less swelling compared with the unconfined case (i.e. reduced final specific volume and less change in volume during swelling). The third condition is behind the retaining wall (soil element 3). As the soil swells, volumetric confinement is provided by the retaining wall. Thus, as the soil swells it encounters the stiff retaining wall, which deflects in response to the lateral stress. In V-p space (Figure 1b), an upward sloping stress-volume path results in increases in both volume and stress until the soil's swelling potential is realized. The stiffer the wall, the flatter the stress-volume path. For perfect confinement a horizontal stress-volume path is followed, termed constant volume (CV). For each of the three conditions the soil swells until its swelling potential is satisfied. Connecting the 'swelled state' points on Figure $1 b$ forms the SEL. 
Submitted to Canadian Geotechnical Journal as an Article \#cgj-2015-0049

May 2016

The SEL is an upper limit to swelling that defines the end-of-swelling state. The SEL concept provides a basis to model swelling soil behaviour. The end-of-swelling state is determined from the initial specific volume (related to dry density) and mean stress as well as the boundary conditions during swelling. Siemens and Blatz (2007) developed a triaxial swelling test, which allows for general conditions to be applied during a swelling experiment. Lim and Siemens (2013) developed an unconfined swelling test that incorporates non-contact method to measure soil deformations. Thus, the range of field boundary conditions presented in Figure 1 can be applied experimentally. Currently SELs for a compacted 50:50 bentonite-sand mixture (named bentonite-sand-buffer) and natural Bearpaw shale have been characterized (Siemens and Blatz 2009; Powell et al. 2013). Of interest is the potential to relate SEL parameters to fundamental expansive soil properties. This would allow for estimation of SELs for new soils for use in preliminary analysis. If significant swelling issues are anticipated, an experimental program could then be initiated. In this paper, the swelling results for two swelling soils, Lake Agassiz clay and Bearpaw clay, are reported and their SELs are interpreted. The SEL parameters for the characterized soils are successfully related to expansive soil index properties and initial specific volume. Finally the SEL for Regina clay is successfully estimated and compared with published data.

\section{MATERIALS AND METHODS}

\section{Materials}

The swelling properties of three expansive soils: Lake Agassiz clay, Bearpaw clay and bentonitesand-buffer, are examined in this study. Index properties of the soils are summarized in Table 1 and Figure 2. The swelling soils examined for this study were selected to have a range of clay fraction, montmorillonite fraction, consistency limits, free swell potential, and activity (Table 1).

Lake Agassiz clay is a high plasticity freshwater clay (Graham et al. 1983) of glacial origin from southern Manitoba, Canada. The consistency limits are $\mathrm{LL}=85 \%, \mathrm{PL}=34 \%$, and $\mathrm{PI}=51 \%$ (ASTM 
Submitted to Canadian Geotechnical Journal as an Article \#cgj-2015-0049

May 2016

D4318) and the grain size distribution (Figure 2a) consisting of $75 \%$ clay and $20 \%$ silt. Modified optimum dry density and water content are $1.62 \mathrm{Mg} / \mathrm{m}^{3}$ and $20 \%$ (ASTM D1557). Soil specimens were prepared to modified optimum dry density and water content.

Bearpaw clay, taken from the Bearpaw formation, consists of predominately marine silty clays and sands. The consistency limits of the Bearpaw clay were $\mathrm{LL}=67 \%, \mathrm{PL}=26 \%$ and $\mathrm{PI}=41 \%$. The $\mathrm{LL}=145 \%$ and $\mathrm{PI}=122 \%$ of natural Bearpaw shale were higher than the soil tested due to drying of samples prior to specimen preparation (Rao et al. 1989). The clay fraction and montmorillonite content for Bearpaw shale is 39\% (Figure 2a) and 72\% (Bryne and Farvolden 1959), respectively. Bearpaw shale, in its natural state, was previously tested for its SEL (Powell et. al. 2013) and the same soil was re-used in this research. The Bearpaw shale was dried, pulverized, and compacted to a target dry density and moisture content of its insitu state: $1.50 \mathrm{Mg} / \mathrm{m}^{3}$ dry density and $30 \%$ gravimetric moisture content. The preparation procedures removed depositional and aging effects (Powell et al. 2012b) and allowed for comparison with the other materials in this study.

Bentonite-sand-buffer consists of 50\% sand and 50\% Wyoming bentonite by mass (Dixon et al., 1994). The consistency limits of bentonite-sand buffer are $\mathrm{LL}=265 \%, \mathrm{PL}=21 \%, \mathrm{PI}=244 \%$. Specimens were compacted to target dry density and gravimetric water content of $1.65 \mathrm{Mg} / \mathrm{m}^{3}$ and $19.4 \%$, which are the specifications for the Canadian concept of a deep geological repository (Dixon et al. 1994).

\section{Triaxial Swelling Specimen Preparation, Apparatus, and Test Method}

Test specimens were prepared to a target dry density and water content condition following procedures detailed in Siemens (2006). A required amount of dry mass of pulverized soil was weighed. The dry pulverized soil was moistened thoroughly with a targeted amount of de-ionized water within a mixing bowl. The moist soil was kept in a double-layered sealed plastic bag and placed in the refrigerator for 24 hours for moisture equilibrium. After 24 hours, the moist soil was compacted in 5- 
Submitted to Canadian Geotechnical Journal as an Article \#cgj-2015-0049

May 2016

layers in a $50.8 \mathrm{~mm}$ diameter compaction mold. The compacted triaxial specimen was installed in the modified triaxial apparatus (see Figure 3).

The triaxial swelling apparatus, previously used by Siemens and Blatz $(2007,2009)$ and Powell et al. (2013), was modified to allow for suction measurement device installation within the triaxial pedestal (Figure 3). Internal suction measurement provides information on the internal moisture response during a swelling test, data to be used in future numerical simulations, and is one of the end-oftest criteria. Previously a suction measurement probe was installed at the center of the specimen, however, the sensor was no longer commercially available. An extensive search for a replacement did not turn up any sensors that met small size and high accuracy requirements. Blatz and Graham (2000) noted that total suction measurements taken near the top cap gave similar readings as those taken at the center of the specimen, however, locating a sensor within the top cap still has size-limiting constraints. No notable effect on mechanical or suction behaviour during isotropic compression or shear loading was found due to compaction of sensors within triaxial specimens (Blatz et al. 1999). Locating the sensor within the pedestal allowed for probe installation prior to the test, which was, operationally, a significantly more efficient method compared with compaction at the center of test specimens. A grooved pedestal cap replaced the lower porous stone installation. The water flowed through the fanning groove at the pedestal cap, through the geotextile and infiltrated the specimen. The chamber beneath the cap contained the relative humidity sensor. On the top of the pedestal cap, a perforated cylindrical tip protruded from the cap. The triaxial specimen was installed on the pedestal with the tip inserted into a pre-bored hole at the bottom of the specimen. The specimen equilibrated with the vapor inside the confined chamber where the relative humidity sensor was housed. Total suction was calculated using the Kelvin equation:

$$
\Psi_{t}=-\frac{R T}{v_{w 0} \omega_{v}} \ln (R H)
$$


Submitted to Canadian Geotechnical Journal as an Article \#cgj-2015-0049

May 2016

where $\Psi_{\mathrm{t}}=$ total suction, $R=$ universal gas constant $(8.314 \mathrm{~J} / \mathrm{mol} \mathrm{K}), T=$ absolute temperature $(\mathrm{K})$, $v_{w 0}=$ specific volume of water $\left(\mathrm{m}^{3} / \mathrm{kg}\right), \omega_{v}$ is the molecular mass of water vapor $(18.016 \mathrm{~kg} / \mathrm{kmol})$ and $R H=$ relative humidity.

A typical triaxial swelling test consisted of three phases including isotropic compression at constant water content, suction sensor equilibration, and swelling. Isotropic compression and equilibration occurred as the cell pressure was raised up to a target stress level and held constant. After 24 hours, suction equilibration at the specimen was achieved. To initiate the swelling phase, the back pressure was raised and the plumbing and geotextile were flooded. The initially unsaturated specimen accepted water until the specimen equilibrated with the moisture and stress regimes. The completion of a swelling phase was indicated by less than $\pm 2 \%$ changes in water content, total suction, cell pressure, and volumetric strain over a one-day period.

During the swelling phase, specimens were subjected to simulated field conditions by controlling

the boundary conditions (Figure 1). The specimens consist of initially unsaturated expansive soil and, therefore, had a swelling potential prior to being given access to water. A constant mean stress (CMS) stress-volume path was one where the specimen was allowed to swell under a constant cell pressure to measure the volumetric swelling potential at a particular stress level. The stress-volume path was set to move vertically along y-axis in a V-p plot (Figure 1b). In the second boundary condition, a constant volume $(\mathrm{CV})$ test, measured the swelling-induced-stress potential at a constant volume. During the CV test, the initial volume of the specimen was maintained constant by increasing the confining pressure. The stress-volume path followed during a CV test moved horizontally in V-p space (Figure 1b).

\section{Unconfined Swelling Test Method}

An unconfined swelling test (Lim and Siemens 2013) represented the scenario where the swelling soil was free to expand under zero confinement (notwithstanding the self-weight of the specimen). The results from an unconfined swelling test defined the maximum volumetric swelling 
Submitted to Canadian Geotechnical Journal as an Article \#cgj-2015-0049

May 2016

potential. The unconfined swelling tests were carried out in a humidity-controlled chamber. The specimens were given direct access to water through spraying as well as wicking action from a reservoir. Deformations were measured with a non-contact method incorporating digital image analysis (GeoPIV, White et al. 2003).

\section{RESULTS}

\section{Typical Results}

Triaxial Constant Volume (CV) Swelling Test

Results from a typical CV swelling test for Lake Agassiz clay (CV150) are presented in Figure 4 as mean stress, volumetric strain, total suction, and gravimetric water content versus time (Figure 4a-d respectively). Following preparation and installation, the isotropic compression phase was initiated with cell pressure raised to $150 \mathrm{kPa}$. After 24 hours, total suction of $9.1 \mathrm{MPa}$ and volumetric strain was $0.72 \%$. The test continued with the CV swelling phase. When water infiltrated into the specimen, it expanded a small, but detectable, amount. The stress-volume path control algorithm activated and increased cell pressure to suppress expansion. The cell pressure increased from $150 \mathrm{kPa}$ up to $750 \mathrm{kPa}$ to maintain initial volume. During infiltration, the water content (Figure 4d) increased asymptotically to 29.0\%. The total suction response (Figure 4c) showed a slower rate of dissipation compared to the mean stress and water content plots since the measurement is at the center of the specimen rather than at the perimeter. Total suction dissipated after 5 days of infiltration. The end-of-test criteria were satisfied after 25 days.

Triaxial Constant Mean Stress (CMS) Swelling Test

Results from a typical CMS swelling test for Lake Agassiz clay (CMS150) are presented in Figure 5 as mean stress, volumetric strain, total suction, and gravimetric water content versus time (Figure 5a-d respectively). The mean stress was raised to $150 \mathrm{kPa}$ for the constant water content Lim and Siemens, 2016 Page 9 of 26 
Submitted to Canadian Geotechnical Journal as an Article \#cgj-2015-0049

May 2016

isotropic compression and suction sensor equilibration phases. After 24 hours, total suction and volumetric strain values were measured at $6.5 \mathrm{MPa}$ and $0.45 \%$. During the CMS swelling phase, the volumetric strain and gravimetric water content versus time graphs (Figure $5 \mathrm{~b}$ and $5 \mathrm{~d}$ ) visually resemble each other. As the specimen took on water it also expanded under the constant stress boundary condition. The rate of change for both curves was relatively higher at the beginning of the swelling test phase and then tapered off asymptotically. The end-of-test criteria were satisfied after 35 days.

\section{Unconfined Swelling Test}

Figure 6 and Table 3 presents typical unconfined swelling test results for Lake Agassiz clay and Bearpaw clay. The Lake Agassiz clay swelled at a high rate for the first two days after water application. By the second day, the volumetric strain obtained $80 \%$ of the total change over the test. Subsequently, the swelling rate leveled off over time. For Lake Agassiz clay, the final total volumetric strain was $-70 \%$ (in swelling). The Bearpaw clay specimen behaved similarly to the Lake Agassiz clay but at reduced magnitudes for both swelling strain and swelling rate. At the end of the unconfined swelling test the Bearpaw clay specimen had expanded to $-46 \%$ volumetric strain.

\section{Lake Agassiz Swelling Tests}

A series of five triaxial swelling tests were performed on the Lake Agassiz clay. The test series consisted of CMS150, CMS300, CMS600, CV150, and CV300 tests (detailed results for CV150 and CMS150 appear in Figure 4 and 5). Figure 7a plots mean stress versus time for the five tests. Mean stress in CMS600, CMS300 and CMS150 was kept at a constant level, e.g., at $600 \mathrm{kPa}, 300 \mathrm{kPa}$ and 150 $\mathrm{kPa}$, throughout the swelling phase. Specimen CV300 required the highest mean stress of $1200 \mathrm{kPa}$ to counteract the swelling potential during the constant volume swelling phase. The second highest mean stress is measured in CV150 which required mean stress of $750 \mathrm{kPa}$ to maintain the constant volume. 
Submitted to Canadian Geotechnical Journal as an Article \#cgj-2015-0049

May 2016

A summary of the volumetric strain versus time results for the Lake Agassiz clay swelling tests is plotted in Figure 7b. The maximum swelling strain was measured in the CMS150 as it had the lowest applied mean stress. Volumetric swelling decreased with increasing applied mean stress in the CMS300 and CMS600 experiments. In the two constant volume tests, acceptable control of volume was attained during swelling for both CV150 and CV300 as indicated by the horizontal plots of volumetric strain versus time.

The triaxial swelling and unconfined swelling test results are plotted in Figure 8 in specific volume versus mean stress (V-p) space to allow for interpretation of the SEL for Lake Agassiz clay. The test paths started at a target specific volume of specimen of 1.73 and zero mean stress. The unconfined swelling test swelled along a vertical stress-volume path to the equilibrium value of $\mathrm{V}=3.0$. The triaxial swelling tests began with the isotropic compression stage to 150,300 , or $600 \mathrm{kPa}$ mean stress. Results from the isotropic compression stage provided information on the compressibility of the material. During infiltration, the stress-volume path followed the specified boundary condition resulting in a vertical path for CMS and a horizontal path for CV tests. CMS150, CMS300, and CMS600 terminated at specific volumes of $1.99,1.88$, and 1.80 , respectively. The CV150 and CV300 swelling tests followed horizontal stress-volume paths during swelling. The test results indicated that a higher mean stress was required in CV300 (p=1200 kPa) than CV150 (p=750 kPa) to maintain constant volume. Finally, the SEL was formed by optimizing a function to coincide with the end-of-test states from triaxial and unconfined swelling tests.

\section{Bearpaw Clay Swelling Tests}

A series of triaxial and unconfined swelling tests were performed on Bearpaw clay (5 tests). Triaxial swelling test results are plotted as mean stress and volumetric strain versus time in Figure 9a and Figure 9b (with detailed results in Lim, 2014). Five (5) triaxial swelling tests are shown performed at isotropic pressures of 200 and $400 \mathrm{kPa}$. Summaries of the initial and end-of-test conditions are given 
Submitted to Canadian Geotechnical Journal as an Article \#cgj-2015-0049

May 2016

in Table 1 and Table 2. At $200 \mathrm{kPa}$, volumetric swelling strains of -0.1 to $-1.1 \%$ are measured. The CV400 test only required an additional $10 \mathrm{kPa}$ to maintain the constant volume conditions. Collapse was observed in the two CMS400 tests. In both CMS400 tests, the specimens were brought to $400 \mathrm{kPa}$ isotropic stress and then the swelling phase was initiated. As water infiltrated, the specimens compressed to volumetric strains of $4.1 \%$ and $6.7 \%$. Thus $400 \mathrm{kPa}$ was greater than the swelling potential of Bearpaw clay for the conditions tested.

\section{DISCUSSION}

In this section the experimental results are interpreted from a SEL perspective and a swelling pressure perspective and then the new unifying framework for modeling swelling behaviour is proposed. The SELs for the Lake Agassiz clay, Bearpaw clay and bentonite-sand-buffer are plotted in Figure 10a-c. The plots include end-of-test mean stress and specific volume states from triaxial swelling tests (open symbols) and unconfined tests (closed symbols), SELs, and the isotropic compression lines. The isotropic compression line denotes the compressibility of the soil when subjected to isotropic compression at constant water content. The SELs were evaluated from a spreadsheet solution assuming a natural logarithm equation in the form of:

$$
V_{S E L}=A+B \ln p
$$

where ' $A$ ' represents the $y$-intercept at $p=1$ and parameter ' $B$ ' reflects the curvature. A spreadsheet was used to minimize the square of the difference between the measured value and the predicted value. A nominal stress of $0.1 \mathrm{kPa}$ is assumed for the unconfined tests to make equation [2] calculable. SEL parameters are listed on Figure 10 and in Table 4. The SELs are comparable with the experimental data with specific volume modeled within +-0.01 for Lake Agassiz and +-0.02 for Bearpaw clay.

In addition to the tests reported here, Figure 10 includes a summary of triaxial swelling tests performed on bentonite-sand-buffer (Siemens and Blatz, 2009) in Figure 10c. The plot includes the SEL, 
Submitted to Canadian Geotechnical Journal as an Article \#cgj-2015-0049

May 2016 isotropic compression curve, and the swelling potential. The parameters for the optimized SEL parameters are listed on the figure as well as in Table 4. The bentonite-sand-buffer tests were performed prior to development of the unconfined test methodology (Lim and Siemens 2013) so only triaxial swelling results are shown on Figure 10c. The results for bentonite-sand-buffer indicate the SEL captures the observed swelling behaviour. The results also show that the soil is expansive over a wider range of stresses than those examined. At $1500 \mathrm{kPa}$ mean stress, expansion was measured under CMS boundary conditions and an additional $400 \mathrm{kPa}$ of swelling-induced stress was required to maintain the initial volume for the CV1500 test.

The swelling test results in Figure 10 provide insight into the variable swelling potential of each expansive soil. The area between the isotropic compression line and the SEL is highlighted as the swelling potential in Figures 10a-c. The isotropic compression phase sets the starting point for the swelling test. During the swelling phase, the swelling potential is realized as volumetric expansion, swelling-induced stress, or a combination of both depending on the boundary conditions. The results indicate that Lake Agassiz clay is expansive over the range of stresses tested while the maximum swelling potential of Bearpaw clay was achieved. In Figure 10a the SEL for Lake Agassiz clay is approaching the isotropic compression curve, however, the soil still has swelling potential at the maximum stress tested. The CV300 test required $1200 \mathrm{kPa}$ of mean stress to suppress expansion and volumetric expansion was observed in the CMS600 test. Similarly the isotropic compression line and SEL for bentonite-sand-buffer are converging at $2000 \mathrm{kPa}$ (Figure 10c). The SEL for Bearpaw clay connects with the isotropic compression line at approximately $300 \mathrm{kPa}$ (Figure 10b). Swelling tests performed at stresses greater than $300 \mathrm{kPa}$ had nominal swelling-induced-stress or collapse. Thus at stresses below $300 \mathrm{kPa}$ Bearpaw clay is expansive and at stresses above $300 \mathrm{kPa}$ the swelling potential is overcome. This is the first time in which collapse has been observed during this type of triaxial swelling test. 
Submitted to Canadian Geotechnical Journal as an Article \#cgj-2015-0049

May 2016

Comparing the size and shape of the swelling potential (indicated by the grey shaded area in

Figure 10a-c) gives insight into swelling behaviour from the SEL perspective. A straightforward observation is that a larger shaded area indicates higher swelling potential. Thus bentonite-sand-buffer has the highest swelling potential followed by Lake Agassiz clay and then Bearpaw clay. The shape of the shaded area is a function of the SEL slope and the compressibility of the soil during isotropic compression. The SEL has a steeper slope than the isotropic compression line for the three soils. At the intersection of the two lines the swelling potential is overcome, as in the case of Bearpaw clay. For bentonite-sand-buffer and Lake Agassiz clay, the SEL is asymptotically approaching the isotropic compression line and they will intersect at a mean stress above the available test results.

\section{Interpreting Swelling Pressure with EMDD}

Traditionally expansive soils are characterized by measuring the swelling pressure utilizing one or more of the available methods (ASTM D4546; Wiebe et al. 1998; Yong 1999; Al-Shamrani and AlMhaidib 2000; Aversa and Nicotera 2002; Sánchez et al. 2008; Ferber et al. 2009; Baille et al. 2010; Mohajerani et al. 2011; Powell et al. 2012a; Wang et al. 2012; Powell et al. 2013; Cui et al. 2014; Liu et al. 2014; Abbas et al. 2015). The major clay constituent that contributes to the swelling potential is the montmorillonite content of the material (Mitchell and Soga 2005). The majority of swelling tests found in the literature are one-dimensional (1D) swelling tests performed in an oedometric apparatus. In order to compare the triaxial swelling test results with results from the literature, two calculations are required. First, as the 1D swelling pressure database is for laterally confined tests, the stresses in the triaxial swelling tests must be converted to equivalent vertical swelling pressures before plotting on Figure 11. Siemens and Blatz (2009) developed a conversion equation to convert 1D swelling pressures to mean stress (or vice versa). The derivation used Hooke's law and the relationship took the following form:

$$
p_{\text {equil }}=\frac{p_{\text {swell }}}{3}\left(\frac{1+v}{1-v}\right)
$$


Submitted to Canadian Geotechnical Journal as an Article \#cgj-2015-0049

May 2016

where $p_{\text {equil }}$ is the equilibrium mean stress from end of the triaxial swelling test, $p_{\text {swell }}$ is the $1 \mathrm{D}$ swelling pressure and $v$ is the Poisson's ratio of the soil.

Second, the montmorillonite component of each material is normalized using the Effective Montmorillonite Dry Density equation (EMDD, Dixon et al. 2002). EMDD is defined as the mass of montmorillonite divided by the volume of swelling materials and voids. An equivalent definition is the mass of montmorillonite divided by the volume not occupied by non-clay and non-swelling materials. EMDD is calculated as:

$$
\left.E M D D=\frac{f_{m} f_{c} \rho_{d}}{1-\frac{\left(1-f_{c}\right) \rho_{d}}{G_{s} \rho_{w}}-\frac{\left(1-f_{m}\right) f_{c} \rho_{d}}{G_{n} \rho_{w}}}\right]
$$

where $f_{m}$ is the montmorillonite fraction of clay, $f_{c}$ is the fraction of clay, $\rho_{d}$ is the dry density of soil, $\rho_{w}$ is the density of water, $G_{s}$ is the specific gravity of non-clay soil, $G_{n}$ is the specific gravity of nonswelling clay. Calculating EMDD allows for comparison of different materials with variable clay content, montmorillonite content, and dry density. The converted swelling pressure for Lake Agassiz clay, Bearpaw clay, and bentonite-sand-buffer as well as swelling pressure results taken from Dixon et al. (2002) are plotted in Figure 11.

Dixon et al. (2002) proposed an exponential relationship between swelling pressure and EMDD, which is:

$$
p_{\text {swell }}=C * e^{\left(D^{*} E M D D\right)}
$$

where ' $\mathrm{C}$ ' is the theoretical value of $\mathrm{p}_{\text {swell }}$ at $\mathrm{EMDD}=0$ ' $\mathrm{C}$ ' and ' $\mathrm{D}$ ' is the slope of the line in log-linear space. A spreadsheet solution was implemented to minimize the difference between the experimental data plotted in Figure 11 and Equation [5] for each soil. The output was optimized values of ' $C$ ' and ' $D$ ' for each soil, which are listed in Table 4. The optimized lines show visual and quantitative agreement with the experimental data as swelling pressures are predicted within an average of $11 \%$ of the actual. 
Submitted to Canadian Geotechnical Journal as an Article \#cgj-2015-0049

May 2016

The bentonite-sand-buffer data also shows general agreement with the database of 1D swelling pressures with the triaxial swelling test results show less scatter. Comparing the ' $C$ ' and ' $D$ ' parameters for each soil (Table 4) shows they follow anticipated trends based on their swelling potential. Ranking the materials in order of greatest to least values of parameter ' $\mathrm{C}$ ' is bentonite-sand-buffer, Lake Agassiz clay, and Bearpaw clay. Ranking the materials in increasing order for parameter ' $\mathrm{D}$ ' is bentonite-sandbuffer, Bearpaw clay, and Lake Agassiz clay. The highest swelling potential is represented by the highest ' $C$ ' $\left(7.609 \times 10^{-3}\right)$ value with lowest ' $D$ ' (4.56) value in bentonite-sand-buffer. Lake Agassiz and Bearpaw clays have a steeper slope compared to bentonite-sand-buffer (Figure 11). The EMDD lines for the clays are located at lower EMDD owing to their reduced montmorillonite content and dry density. The steeper slope in the clays is an indication that the swelling pressure is more sensitive to increases in EMDD.

\section{Unifying Framework for SEL Prediction}

In this section a unifying framework for predicting SELs from basic soil properties is proposed. The SEL concept has been utilized to characterize swelling potential of a number of expansive soils, however, the length of time for each test is $2-5$ weeks per test. Therefore the question arises whether SEL equation parameters could be related to more fundamental soil properties as performed by numerous researchers (Shi et al. 2002; Komine and Ogata 2003; Prakash and Sridharan 2004; Rao et al. 2004; Ito and Azam 2010; Cui et al. 2012; Ito and Azam 2013). In a similar focus, Nagaraj and Srinivasa Murthy (1986) and Burland (1990) developed relationships between index properties and compressibility curves. The SEL curves are represented with equation [2] in a V-p plot (Figure 10) or

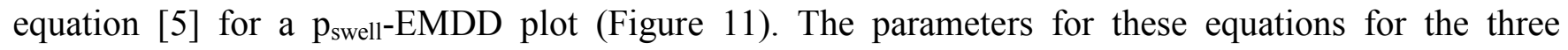
expansive soils are listed in Table 4. Thus a parametric study was performed to explore empirical relationships between soil properties and SEL parameters. Liquid limit, plasticity index, free swell potential, and initial specific volume (related to dry density) were found to correlate well to SEL 
Submitted to Canadian Geotechnical Journal as an Article \#cgj-2015-0049

May 2016

parameters. Figure 12 and Figure 13 plot the relationships between parameters 'A' and 'B' with the correlated soil properties. The SEL parameters 'A' and 'B' show a visual and quantitative correlation relationship to initial specific volume, liquid limit, free swell, and plasticity index. Using the equations displayed on the figures parameters ' $\mathrm{A}$ ' and ' $\mathrm{B}$ ' calculated to within an average of $1.0 \%$ and $4.2 \%$ respectively. The relatively wide range of values, especially those related to plasticity gives increased confidence to the validity of the relationship. At this point a straight-line equation is utilized to relate the soil properties to the SEL parameters. However, as more soils are characterized a higher order relationship may be justifiable.

The benefit of this framework is to allow for estimation of SEL curves for soils that have not been subjected to advanced triaxial swelling tests. This concept could be used in preliminary design calculations where swelling issues are anticipated. Table 1 lists the index properties and initial volume state of Regina clay, which was characterized by Fredlund (1975). These properties of Regina clay are used to calculate the SEL parameters ' $\mathrm{A}$ ' and ' $\mathrm{B}$ ' as detailed in Table 5. The predicted SEL from each pair of parameters varies by just $1-3 \%$. Thus the average of each parameter was used to estimate the SEL for Regina clay $(A=2.644$ and $B=-0.133)$ and the preliminary $S E L$ is $V_{\text {Regina }}=2.644-0.133 \ln (p)$. The SEL for Regina clay is plotted in Figure 14 compared with the test data from Fredlund (1975). The estimated SEL of Regina clay shows visual and quantitative agreement with the experimental data. Specific volume is predicted within $+-20 \%$ for the entire range and within $+-5 \%$ for stresses above 75 $\mathrm{kPa}$ thus giving confidence to the unifying framework for the SEL concept.

\section{CONCLUSIONS}

The destructive effect of expansive soils on infrastructure is one of the classical issues associated with unsaturated soils. Given the continuing challenges associated with swelling soils the need for a practical analysis method is apparent. The SEL provides a conceptual basis for modeling behaviour of expansive soils. It is an upper bound swelling limit, which depends on the soil's initial state and the Lim and Siemens, 2016

Page 17 of 26 
Submitted to Canadian Geotechnical Journal as an Article \#cgj-2015-0049

May 2016

stress-volume paths upon wetting. The SEL curve obtained from triaxial and unconfined swelling tests encompasses the range of potential swelling scenarios from a rigid boundary to free swell. This paper presents improvements to the triaxial swelling apparatus, SELs for Lake Agassiz clay and Bearpaw clay, and proposed a framework to relate SEL parameters to basic soil properties. The newly characterized SELs allow for development of a unifying framework and preliminary estimation of SEL parameters for yet uncharacterized expansive soils. Using this framework the SEL for Regina clay was successfully estimated. At this time the framework is based on the number of soils characterized (i.e. three) and therefore, further testing is required to build-up the SEL database to increase the range of applicability and refinement of the relationships. 


\section{REFERENCES}

Abbas, M.F., Elkady, T.Y. and Al-Shamrani, M.A. 2015. Evaluation of strain and stress states of a compacted highly expansive soil using a thin-walled oedometer. Engineering Geology, 193: 132145.

Adem, H. and Vanapalli, S. 2015. Soil-environment interactions modelling for expansive soils. Environmental Geotechnics, (doi: 10.1680/envgeo.13.00089).

Al-Mhaidib, A. 1998. Swelling behaviour of expansive shales from the middle region of Saudi Arabia. Geotechnical \& Geological Engineering, 16(4): 291-307.

Al-Shamrani, M.A., and Al-Mhaidib, A.I. 2000. Swelling behavior under oedometric and triaxial loading conditions. Advances in Unsaturated Soil, Seepage, and Environmental Geotechnics (GSP 148), 148: 344-360.

Al-Shamrani, M.A., and Dhowian, A.W. 2003. Experimental study of lateral restraint effects on the potential heave of expansive soils. Engineering Geology, 69: 63-81.

ASTM. 2003. Standard test methods for one-dimensional swell or settlement potential of cohesive soils. ASTM standard D4546. American Society for Testing and Materials (ASTM), West Conshoshocken, $\mathrm{Pa}$.

ASTM. 2009. Standard test methods for laboratory compaction characteristics of soil using modified effort. ASTM standard D1557. American Society for Testing and Materials (ASTM), West Conshoshocken, $\mathrm{Pa}$.

ASTM. 2010. Standard test methods for liquid limit, plastic limit, and plasticity index of soils. ASTM standard D4318. American Society for Testing and Materials (ASTM), West Conshoshocken, $\mathrm{Pa}$.

ASTM. 2011. Standard Test Method for Swell Index of Clay Mineral Component of Geosynthetic Clay Liners D5890. American Society for Testing and Materials (ASTM), West Conshoshocken, Pa. 
Submitted to Canadian Geotechnical Journal as an Article \#cgj-2015-0049 May 2016

Aversa, S. and Nicotera, M. 2002. A triaxial and oedometer apparatus for testing unsaturated soils. Geotechnical Testing Journal, 25(1): 3-15.

Baille, W., Tripathy, S., and Schanz, T. 2010. Swelling pressures and one-dimensional compressibility behaviour of bentonite at large pressures. Applied Clay Science, 48: 324-333.

Blatz, J., Tang, G. X., Graham, J., and Wan, A. 1999. Psychrometer techniques for measuring suction in the triaxial test. In Proceedings of the $52^{\text {nd }}$ Canadian Geotechnical Conference, Regina, Sask., Canada, 25-27 October 1999, pp. 617-622.

Blatz, J.A., and Graham, J. 2000. A system for controlled suction in triaxial tests. Géotechnique, 50(4): 465-478.

Briaud, J.L., Zhang, X., and Moon, S. 2003. Shrink test-water content method for shrink and swell predictions. Journal of Geotechnical \& Geoenvironmental Engineering, 129(7): 590-600.

Bryne, P.J.S., and Farvolden, R.M. 1959. The clay mineralogy and chemistry of the Bearpaw Formation of southern Alberta. Bulletin 4, Geological Division, Research Council of Alberta.

Burland, J.B. 1990. On the compressibility and shear strength of natural clays. Géotechnique, 40(3): 329-378.

Cui, S., Zhang, H., and Zhang, M. 2012. Swelling characteristics of compacted GMZ bentonite-sand mixtures as a buffer/backfill material in China. Engineering Geology, 141-142: 65-73.

Cui, Y., Saba, S., Tang, A. M., and Barnichon, J. 2014. Investigation of the swelling behaviour of compacted bentonite/sand mixture by mock-up tests. Canadian Geotechnical Journal, 51(12): 1399-1412.

Dixon, D.A. 1994. Sodium bentonites of Canada, the United States and Mexico: sources, reserves and properties. Engineering Materials for Waste Isolation, CSCE-Engineering Division-Special Publication, 37-65. 
Submitted to Canadian Geotechnical Journal as an Article \#cgj-2015-0049

May 2016

Dixon, D.A., Campbell, S.L., and Hnatiw, D.S.J. 1994. Preplacement quality control and as-placed properties of the buffer materials used in the URL isothermal buffer experiment. AECL Technical Record TR-612, COG-94-35, Atomic Energy of Canada Ltd., Whiteshell Laboratories, Pinawa, Man.

Dixon, D.A., Chandler, N.A. and Baumgartner, P. 2002. The influence of groundwater salinity and influences on the performance of potential backfill materials. In Proceedings of the 6th International Workshop on Design and Construction of Final Repositories, Backfilling in Radioactive Waste Disposal, Brussels, Belgium, 11-13 March 2002.

Dixon, D.A., Hnatiw, D.S.J. and Kohle, C.L. 1992. Preparation and quality control of materials used on the reference buffer material. Technical Record TR-575, COG-92-133, Fuel Waste Technology Branch, Whiteshell Laboratories, Pinawa, Manitoba.

Ferber, V., Auriol, J., Cui, Y. and Magnan, J. 2009. On the swelling potential of compacted high plasticity clays. Engineering Geology, 104: 200-210.

Fredlund, D.G. 1975. Engineering properties of expansive clays. In Proceedings of the Seminar on Shallow Foundations on Expansive Clays, Regina, Saskatchewan, 27-28 October 1975, pp. 1-58.

Fredlund, D.G. 1983. Prediction of ground movements in swelling clays. In Proceedings of the 31st Annual Soil Mechanics and Foundation Engineering Conference, Earle Brown Centre, University of Minnesota, Minneapolis, Minnesota, 1 February 1983, pp. 1-48.

Graham, J., Noonan, M.L., and Lew, K.V. 1983. Yield states and stress-strain relationships in a natural plastic clay. Canadian Geotechnical Journal, 20: 502-516.

Houston, S., Dye, H., Zapata, C., Walsh, K., and Houston, W. 2011. Study of expansive soils and residential foundations on expansive soils in Arizona. Journal of Performance of Constructed Facilities, 25(1): 31-44. 
Submitted to Canadian Geotechnical Journal as an Article \#cgj-2015-0049

May 2016

Ito, M., and Azam, S. 2010. Determination of swelling and shrinkage properties of undisturbed expansive soils. Geotechnical and Geological Engineering, 28: 413-422.

Ito, M., and Azam, S. 2013. Engineering properties of a vertisolic expansive soil deposit. Engineering Geology, 152(1): 10-16.

Ito, M., and Hu, Y. 2011. Prediction of the behaviour of expansive soils. In Proceedings of the 64th Canadian Geotechnical Conference and 14th Pan-American Conference on Soil Mechanics and Geotechnical Engineering, Toronto, ON, Canada, 2-6 October 2011, pp. 1-8.

Kayabali, K., and Demir, S. 2011. Measurement of swelling pressure: direct method versus indirect methods. Canadian Geotechnical Journal, 48: 354-364.

Kodikara, J. 2012. New framework for volumetric constitutive behaviour of compacted unsaturated soils. Canadian Geotechnical Journal, 49: 1227-1243.

Komine, H., and Ogata, N. 1994. Experimental study on swelling characteristics of compacted bentonite. Canadian Geotechnical Journal, 31(4): 478-490.

Komine, H., and Ogata, N. 2003. New equations for swelling characteristics of bentonite-based buffer materials. Canadian Geotechnical Journal, 40(2): 460-475.

Komine, H., and Ogata, N. 2004. Predicting swelling characteristics of bentonites. Journal of Geotechnical \& Geoenvironmental Engineering, 130(8): 818-829.

Lim, B.F. 2014. Advanced testing and a numerical tool for swell equilibrium limit of expansive soils. Ph.D. thesis, Department of Civil Engineering, Royal Military College of Canada, Kingston, ON.

Lim, B.F., and Siemens, G.A. 2013. An unconfined swelling test for clayey soils that incorporates digital image correlation. Geotechnical Testing Journal, 36(6): 1-11.

Liu, X.F., Buzzi, O.P., and Vaunat, J. 2014. Influence of stress-volume path on swelling behaviour of an expansive clay. In Proceedings of the 6th International Conference on Unsaturated Soils: Research \& Applications, Sydney, Australia, 2-4 July 2014, pp. 931-937. 
Submitted to Canadian Geotechnical Journal as an Article \#cgj-2015-0049 May 2016

Lloret, A., Villar, M.V., Sànchez, M., Gens, A., Pintado, X., and Alonso, E.E. 2003. Mechanical behaviour of heavily compacted bentonite under high suction changes. Géotechnique, 53(1): 2740.

Masia, M.J., Totoev, Y.Z. and Kleeman, P.W. 2004. Modeling expansive soil movements beneath structures. Journal of Geotechnical and Geoenvironmental Engineering, 130(6): 572-579.

Miller, D.J., Durkee, E.B., Chao, K.C., and Nelson, J.D. 1995. Simplified heave prediction for expansive soils. In Proceedings of the 1st International Conference on Unsaturated Soils (UNSAT 95), Paris, France, 6 - 8 September 1995, pp. 891-897.

Mitchell, J.K. and Soga, K. 2005. Fundamentals of soil behavior. John Wiley \& Sons, Canada.

Mohajerani, M., Delage, P., Monfared, M., Tang, A.M., Sulem, J. and Gatmiri, B. 2011. Oedometric compression and swelling behaviour of the Callovo-Oxfordian argillite. International Journal of Rock Mechanics and Mining Sciences, 48(4): 606-615.

Nagaraj, T.S., and Srinivasa Murthy, B.R. 1986. A critical reappraisal of compression index equations. Géotechnique, 36(1): 27-32.

Nagaraj, H.B., Munnas, M.M., and Sridharan. 2009. Critical evaluation of determining swelling pressure by swell-load method and constant volume method. Geotechnical Testing Journal, 32(4): 1-10.

Peterson, R., and Peters, N. 1963. Heave of spillway structures on clay shales. Canadian Geotechnical Journal, 1: 5-15.

Powell, J.S. 2010. Geotechnical characterization of the Bearpaw shale. Ph.D. thesis, Department of Geological Sciences \& Geological Engineering, Queen's University, Kingston, ON.

Powell, J.S., Siemens, G., Take, W.A., and Remenda, V. 2012a. Influence of specimen geometry on sample disturbance observed in oedometric testing of clay shales. Geotechnical Testing Journal, 35(5): 1-13. 
Submitted to Canadian Geotechnical Journal as an Article \#cgj-2015-0049

May 2016

Powell, J.S., Siemens, G., Take, W.A., and Remenda, V. 2013. Characterizing the swelling potential of Bearpaw shale. Engineering Geology, 158: 89-97.

Powell, J.S., Take, W.A., Siemens, G., and Remenda, V. 2012b. Time-dependent behaviour of the Bearpaw shale in oedometric loading and unloading. Canadian Geotechnical Journal, 49: 427441.

Prakash, K., and Sridharan, A. 2004. Free swell ratio and clay mineralogy of fine-grained soils. Geotechnical Testing Journal, 27(2): 1-6.

Puppala, A.J., and Cerato, A.B. 2009. Heave distress problems in chemically-treated sulfate laden materials. GeoStrata, 28-32.

Puppala, A.J., Manosuthikij, T. and Chittoori, B.C.S. 2014. Swell and shrinkage strain prediction models for expansive clays. Engineering Geology, 168: 1-8.

Rampino, C., Mancuso, C. and Vinale, F. 1999. Laboratory testing on an unsaturated soil: equipment, procedures, and first experimental results. Canadian Geotechnical Journal, 36: 1-12.

Rao, A.S., Phanilumar, B.R. and Sharma, R.S. 2004. Prediction of swelling characteristics of remoulded and compacted expansive soils using free swell index. Quarterly Journal of Engineering Geology and Hydrogeology, 37: 217-226.

Rao, B.H., Venkataramana, K., and Singh, D.N. 2011. Studies on the determination of swelling properties of soils from suction measurements. Canadian Geotechnical Journal, 48(3): 375-387.

Rao, S.M., Sridharan, A., and Chandrakaran, S. 1989. Influence of drying on the liquid limit behaviour of a marine clay. Géotechnique, 39(4): 715-719.

Rees, S.W., and Thomas, H.R. 1993. Simulating seasonal ground movement in unsaturated clay. Journal of Geotechnical Engineering, 119(7): 1127-1143. 
Submitted to Canadian Geotechnical Journal as an Article \#cgj-2015-0049 May 2016

Sánchez, M., Villar, M.V., Gens, A., Gómez-Espina, R., and Lloret, A. 2008. Swelling pressure in compacted bentonite: laboratory tests and modelling. In Proceedings of the 1st European Conference on Unsaturated Soils (E-UNSAT 2008), Durham, UK, 2-4 July 2008, pp. 667-674.

Sheng, D., Fredlund, D.G., and Gens, A. 2008. A new modelling approach for unsaturated soils using independent stress variables. Canadian Geotechnical Journal, 45: 511-534.

Shi, B., Jiang, H., Liu, Z., and Fang H.Y. 2002. Engineering geological characteristics of expansive soils in China. Engineering Geology, 67: 63-71.

Shuai, F., and Fredlund, D.G. 1998. Model for the simulation of swelling-pressure measurements on expansive soils. Canadian Geotechnical Journal, 35: 96-114.

Siemens, G.A. 2006. The influence of boundary conditions on the hydraulic-mechanical behaviour of an unsaturated swelling soil. Ph.D. thesis, Department of Civil Engineering, University of Manitoba, Winnipeg, Man.

Siemens, G., and Blatz, J.A. 2007. Triaxial apparatus for applying liquid infiltration with controlled boundary conditions and internal suction measurement. Journal of Geotechnical \& Geoenvironmental Engineering, 133(6): 748-752.

Siemens, G.A., and Blatz, J.A. 2009. Evaluation of the influence of boundary confinement on the behaviour of unsaturated swelling clay soils. Canadian Geotechnical Journal, 46: 339-356.

Sivakumar, V., and Wheeler, S.J. 2000. Influence of compaction procedure on the mechanical behaviour of an unsaturated compacted clay. Part 1: Wetting and isotropic compression. Géotechnique, 50(4): 259-368.

Sun, D., Sheng, D., and Xu, Y. 2007. Collapse behaviour of unsaturated compacted soil with different initial densities. Canadian Geotechnical Journal, 44: 673-686.

Vanapalli, S.K. and Lu, L. 2012. A state-of-the art review of 1-D heave prediction methods for expansive soils. International Journal of Geotechnical Engineering, 6: 15-41. 
Submitted to Canadian Geotechnical Journal as an Article \#cgj-2015-0049 May 2016

Wang, Q., Tang, A.M., Cui, Y., Delage, P., and Gatmiri, B. 2012. Experimental study on the swelling behaviour of bentonite/claystone mixture. Engineering Geology, 124: 59-66.

Wheeler, S. J., and Sivakumar, V. 1995. An elasto-plastic critical state framework for unsaturated soil. Géotechnique, 45(1): 35-53.

White D.J., Take, W.A., and Bolton, M.D. 2003. Soil deformation measurement using particle image velocimetry (PIV) and photogrammetry. Géotechnique, 53(7): 619-631.

Wiebe, B., Graham, J., Tang, G.X., and Dixon, D. 1998. Influence of pressure, saturation and temperature on the behavior of unsaturated sand-bentonite. Canadian Geotechnical Journal, 35: 194-205.

Yilmaz, I. 2006. Indirect estimation of the swelling percent and a new classification of soils depending on liquid limit and cation exchange capacity. Engineering Geology, 85: 295-301.

Yong, R.N. 1999. Soil suction and soil-water potentials in swelling clays in engineered clay barriers. Engineering Geology, 54: 3-13. 
1 Table 1. Properties of soils used in this study.

\begin{tabular}{|c|c|c|c|c|c|c|c|c|c|c|c|}
\hline Soil & $\begin{array}{c}\text { Specific } \\
\text { gravity, } \\
\mathrm{G}_{\mathrm{s}} \\
(-)\end{array}$ & $\begin{array}{c}\text { Clay } \\
\text { fraction, } \\
\mathrm{f}_{\mathrm{c}} \\
(\%)\end{array}$ & $\begin{array}{l}\text { Montmo- } \\
\text { rillonite } \\
\text { fraction of } \\
\text { clay, } \\
\mathrm{f}_{\mathrm{m}} \\
(\%)\end{array}$ & $\begin{array}{l}\text { Liquid } \\
\text { Limit, } \\
\text { LL } \\
(\%)\end{array}$ & $\begin{array}{l}\text { Plastic } \\
\text { Limit, } \\
\text { PL } \\
(\%)\end{array}$ & $\begin{array}{l}\text { Plasticity } \\
\text { Index, } \\
\text { PI } \\
(\%)\end{array}$ & $\begin{array}{l}\text { Free Swell } \\
(\mathrm{mL} / 2 \mathrm{~g})^{5}\end{array}$ & $\begin{array}{l}\text { Activity, } \\
\mathrm{A}=\mathrm{PI} / \mathrm{f}_{\mathrm{c}}\end{array}$ & $\begin{array}{c}\text { Initial dry } \\
\text { density, } \\
\rho_{\mathrm{d}} \\
\left(\mathrm{Mg} / \mathrm{m}^{3}\right)\end{array}$ & $\begin{array}{c}\text { Initial } \\
\text { specific } \\
\text { volume, } \mathrm{V}_{\mathrm{o}} \\
(-)\end{array}$ & $\begin{array}{c}\text { Poisson's } \\
\text { ratio, } \\
v \\
(-)\end{array}$ \\
\hline Lake Agassiz clay & 2.76 & 75 & $30^{1}$ & 85 & 34 & 51 & 6.5 & 0.64 & 1.62 & 1.73 & 0.33 \\
\hline Bearpaw clay & 2.75 & $39^{2}$ & $72^{3}$ & 67 & 26 & 41 & 5.0 & 1.05 & 1.50 & 1.89 & 0.34 \\
\hline Bentonite -sand-buffer & 2.70 & $50^{4}$ & $90^{4}$ & 265 & 21 & 244 & 29 & 4.88 & 1.65 & 1.62 & 0.18 \\
\hline Regina clay (Fredlund 1975) & 2.83 & 51 & 77 & 76 & 26 & 50 & $\mathrm{~N} / \mathrm{A}$ & 1.0 & 1.54 & 1.84 & 0.35 \\
\hline
\end{tabular}

Notes: ${ }^{1}$ Dixon et al., 2002.

${ }^{2}$ Powell et al., 2013.

${ }^{3}$ Bryne and Farvolden, 1959.

${ }^{4}$ Dixon, 1994.

${ }^{5}$ Measured using ASTM, 2011. 
Table 2. Initial and end-of-test measurements for triaxial swelling tests on Lake Agassiz and Bearpaw clays.

\begin{tabular}{|c|c|c|c|c|c|c|c|c|c|c|c|}
\hline \multirow[b]{2}{*}{ Soil } & \multirow[b]{2}{*}{ Test ID } & \multicolumn{3}{|c|}{ Initial (as-compacted) } & \multicolumn{7}{|c|}{ End of triaxial swelling test } \\
\hline & & $\begin{array}{c}\text { Gravimetric } \\
\text { water content, } \\
\mathrm{w}_{\mathrm{o}} \\
(\%)\end{array}$ & $\begin{array}{c}\text { Specific } \\
\text { volume, } \\
\mathrm{V}_{\mathrm{o}} \\
(-)\end{array}$ & $\begin{array}{c}\text { Degree of } \\
\text { saturation, } \\
\mathrm{S}_{\mathrm{r}} \\
(\%)\end{array}$ & $\begin{array}{c}\text { Gravimetric } \\
\text { water } \\
\text { content, } \\
\text { w } \\
(\%) \\
\end{array}$ & $\begin{array}{l}\text { Specific } \\
\text { volume, } \\
\text { V } \\
(-)\end{array}$ & $\begin{array}{c}\text { Volumetric } \\
\text { strain }^{1} \\
\varepsilon_{\mathrm{V}} \\
(\%)\end{array}$ & $\begin{array}{c}\text { Mean } \\
\text { stress, } \\
p_{\text {equil }} \\
(\mathrm{kPa})\end{array}$ & $\begin{array}{c}\text { Water } \\
\text { uptake } \\
(\mathrm{mL})\end{array}$ & $\begin{array}{c}\text { Degree of } \\
\text { saturation, } \\
\mathrm{S}_{\mathrm{r}} \\
(\%)\end{array}$ & $\begin{array}{c}\text { Dry } \\
\text { density, } \\
\rho_{\mathrm{d}} \\
\left(\mathrm{Mg} / \mathrm{m}^{3}\right)\end{array}$ \\
\hline \multirow{5}{*}{ 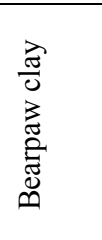 } & CMS200 & 29.3 & 1.87 & 93 & 31.9 & 1.90 & -1.1 & 200 & 23 & 98 & 1.45 \\
\hline & CMS400 & 27.8 & 1.88 & 87 & 31.6 & 1.87 & 0.98 & 400 & 1.8 & 100 & 1.47 \\
\hline & CMS200² & 31.8 & 1.95 & 92 & 33.5 & 1.95 & -0.1 & 200 & 8.9 & 97 & 1.41 \\
\hline & $\mathrm{CMS} 400^{3}$ & 30.9 & 1.95 & 89 & 31.3 & 1.83 & 6.7 & 400 & 2.3 & 97 & 1.46 \\
\hline & CV400 & 29.6 & 1.91 & 90 & 30.8 & 1.83 & 4.1 & 410 & 1.82 & 102 & 1.50 \\
\hline \multirow{5}{*}{ 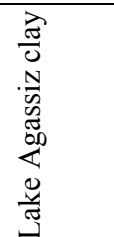 } & CV150 & 21.6 & 1.76 & 79 & 29.0 & 1.76 & -0.06 & 750 & 25 & 105 & 1.57 \\
\hline & CMS150 & 20.3 & 1.74 & 77 & 39.1 & 1.99 & -14.5 & 150 & 62 & 109 & 1.39 \\
\hline & CV300 & 19.0 & 1.72 & 73 & 26.3 & 1.70 & 1.2 & 1200 & 25 & 103 & 1.62 \\
\hline & CMS300 & 21.1 & 1.75 & 78 & 32.4 & 1.88 & -7.3 & 300 & 37 & 102 & 1.47 \\
\hline & CMS600 & 19.3 & 1.75 & 71 & 29.2 & 1.80 & -3.8 & 600 & 33 & 101 & 1.53 \\
\hline
\end{tabular}

9 Notes: All triaxial swelling tests are performed with water pressure at $100 \mathrm{kPa}$.

101 negative value represents expansion; positive value represents compression.

2 test begins with CMS200, then load up with $200 \mathrm{kPa}$ at each stress increment up till $800 \mathrm{kPa}$ under CMS condition.

${ }^{3}$ test begins with CMS400, then unload to $200 \mathrm{kPa}$ under CMS condition. 
14 Table 3. Initial and end-of-test measurements for typical unconfined swelling tests on Lake Agassiz and Bearpaw clays.

\begin{tabular}{|c|c|c|c|c|c|c|c|c|}
\hline \multirow[t]{2}{*}{ Soil Type } & \multicolumn{3}{|c|}{ Initial (as-compacted) } & \multicolumn{5}{|c|}{ End of unconfined swelling test } \\
\hline & $\begin{array}{c}\text { Gravimetric } \\
\text { water content, } \\
\mathrm{w}_{\mathrm{o}} \\
(\%)\end{array}$ & $\begin{array}{c}\text { Specific } \\
\text { volume, } \\
\mathrm{V}_{\mathrm{o}} \\
(-)\end{array}$ & $\begin{array}{c}\text { Degree of } \\
\text { saturation, } \\
\mathrm{S}_{\mathrm{r}} \\
(\%)\end{array}$ & $\begin{array}{c}\text { Water } \\
\text { content, } \\
\text { w } \\
(\%)\end{array}$ & $\begin{array}{c}\text { Specific } \\
\text { volume, } \\
\text { V } \\
(-) \\
\end{array}$ & $\begin{array}{c}\text { Volumetric } \\
\text { strain } 1 \\
\varepsilon_{\mathrm{V}} \\
(\%)\end{array}$ & $\begin{array}{c}\text { Degree of } \\
\text { saturation, } \\
\mathrm{S}_{\mathrm{r}} \\
(\%)\end{array}$ & $\begin{array}{c}\text { Dry } \\
\text { density, } \\
\rho_{\mathrm{d}} \\
\left(\mathrm{Mg} / \mathrm{m}^{3}\right) \\
\end{array}$ \\
\hline Lake Agassiz clay & 20.6 & 1.77 & 74.1 & 67.3 & 3.00 & -70 & 93 & 0.92 \\
\hline Bearpaw clay & 30.0 & 1.88 & 93.8 & 61.8 & 2.74 & -46 & 98 & 1.00 \\
\hline
\end{tabular}

15 Notes: ${ }^{1}$ negative value represents expansion; positive value represents compression. 


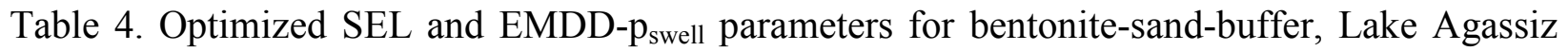
clay, and Bearpaw clay.

\begin{tabular}{lcccc}
\hline Soil & & $V=A+B * \ln (p)$ & & $p_{\text {swell }}=C * e^{(D * E M D D)}$ \\
\cline { 1 - 1 } Bentonite-sand-buffer & & $V=3.023-0.214 \ln p$ & & $p_{\text {swell }}=7.609 \times 10^{-3} * e^{(4.56 * E M D D)}$ \\
Lake Agassiz clay & & $V=2.691-0.141 \ln p$ & & $p_{\text {swell }}=4.966 \times 10^{-4} * e^{(12.27 * E M D D)}$ \\
Bearpaw clay & $V=2.596-0.127 \ln p$ & & $p_{\text {swell }}=1.566 \times 10^{-4} * e^{(11.73 * E M D D)}$ \\
\hline
\end{tabular}


Table 5. Estimated SEL for Regina clay.

\begin{tabular}{|c|c|c|c|c|}
\hline $\begin{array}{l}\text { Index properties } \\
\text { of Regina clay } \\
\text { (Fredlund 1975) }\end{array}$ & Equation & 'A' & Equation & 'B' \\
\hline $\mathrm{V}_{\mathrm{o}}=1.838$ & Figure $12 \mathrm{a}$ & 2.638 & Figure $13 a$ & -0.133 \\
\hline $\mathrm{LL}=76$ & Figure $12 b$ & 2.641 & Figure $13 b$ & -0.132 \\
\hline \multirow[t]{2}{*}{$\mathrm{PI}=50$} & Figure $12 \mathrm{c}$ & 2.653 & Figure $13 c$ & -0.135 \\
\hline & Average & 2.644 & Average & -0.133 \\
\hline
\end{tabular}


Page 33 of $45 \quad$ Canadian Geotechnical Journal
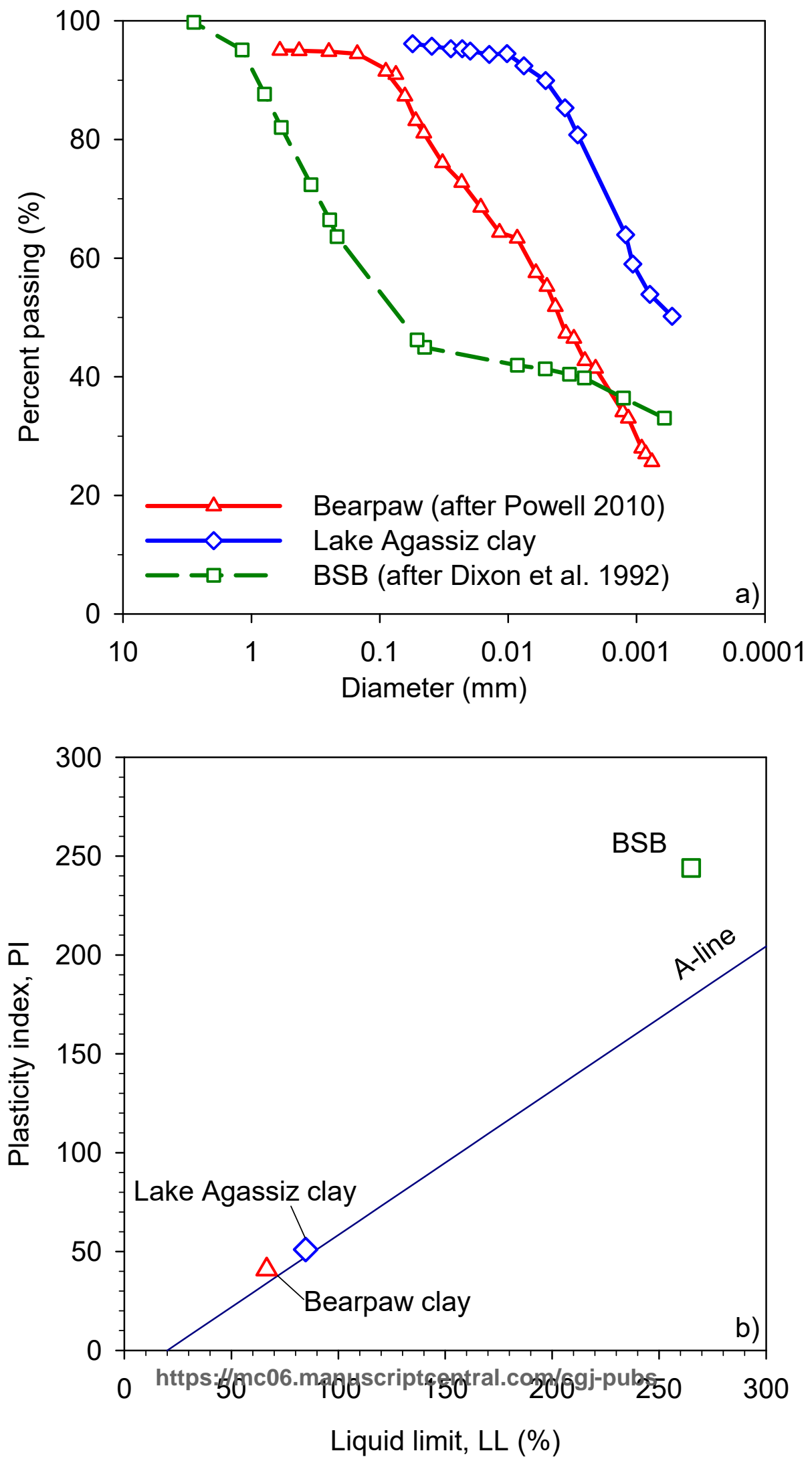

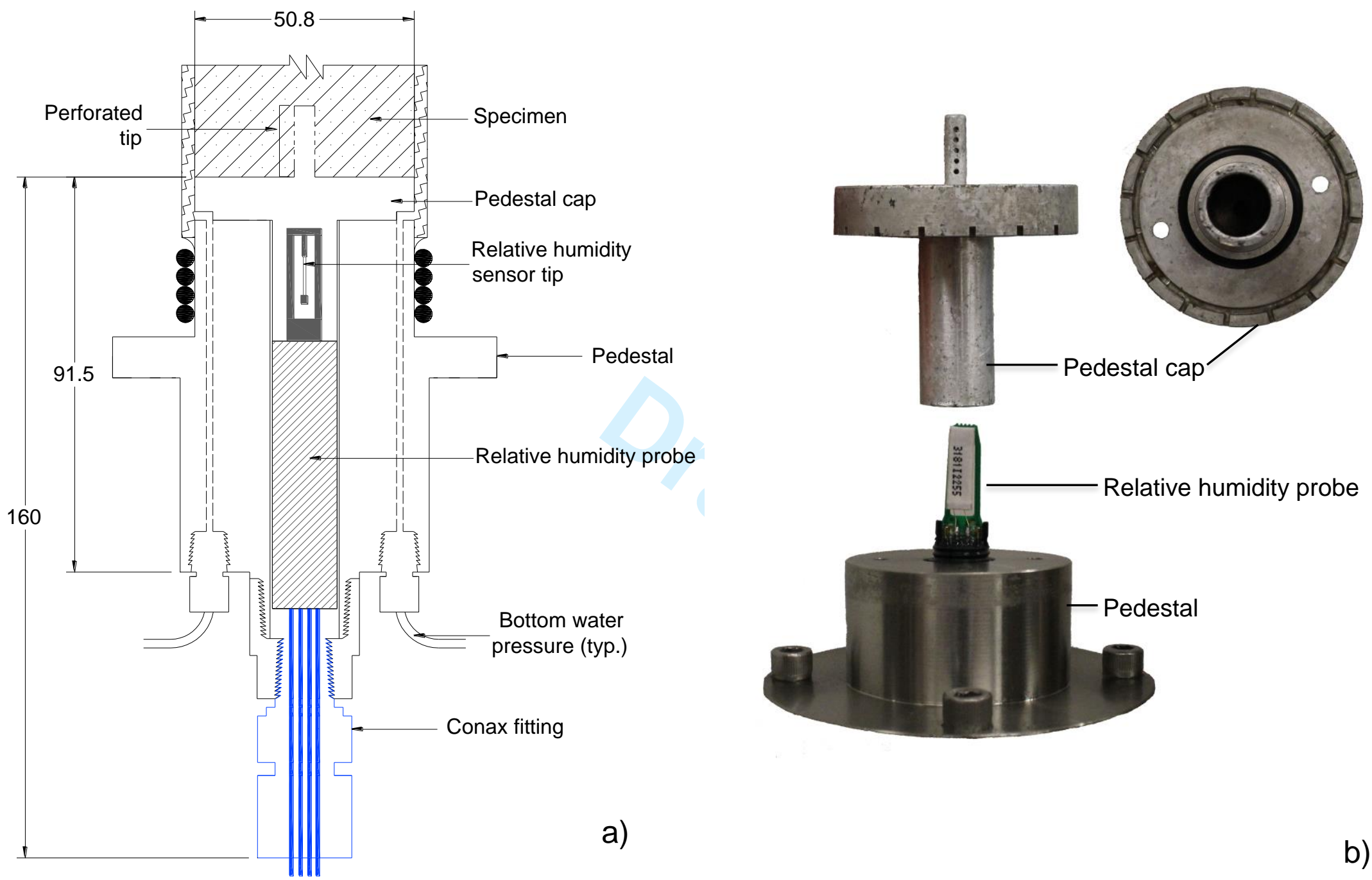

Figure 3. A a) schematic and b) photograph of the suction measurement instrument located within the triaxial pedestal. 
Isotropic compression

and suction sensor equitibration

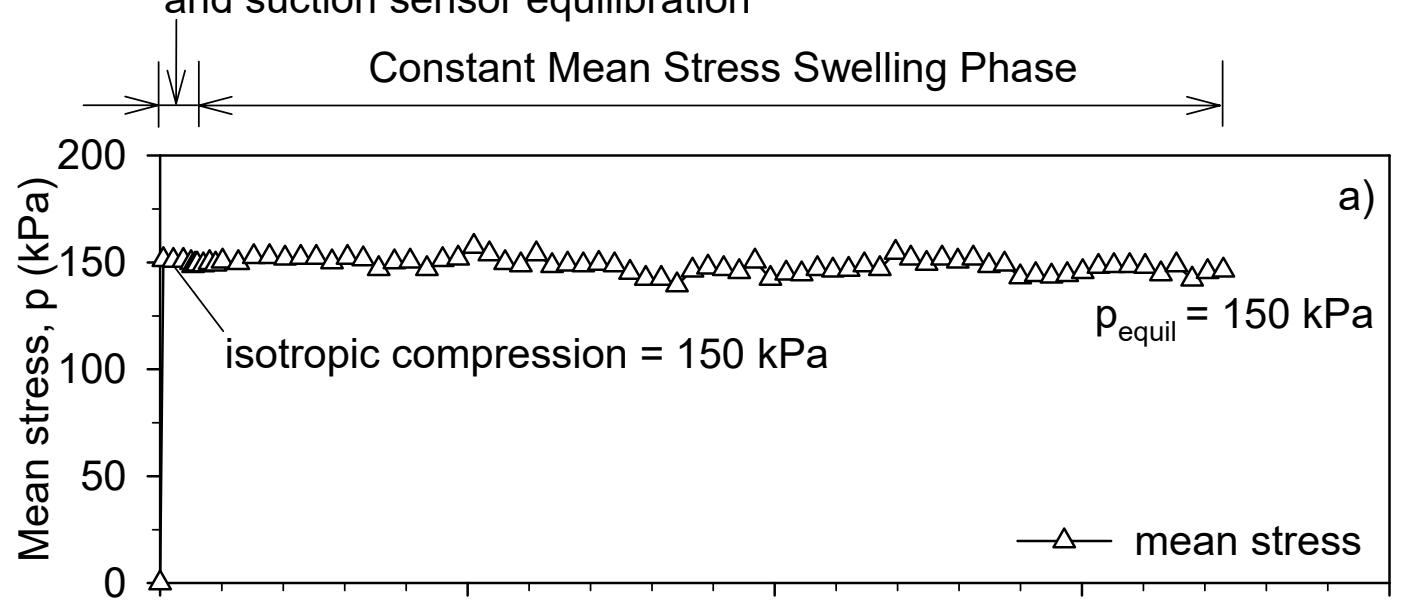

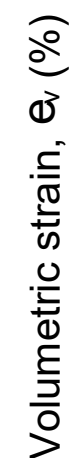

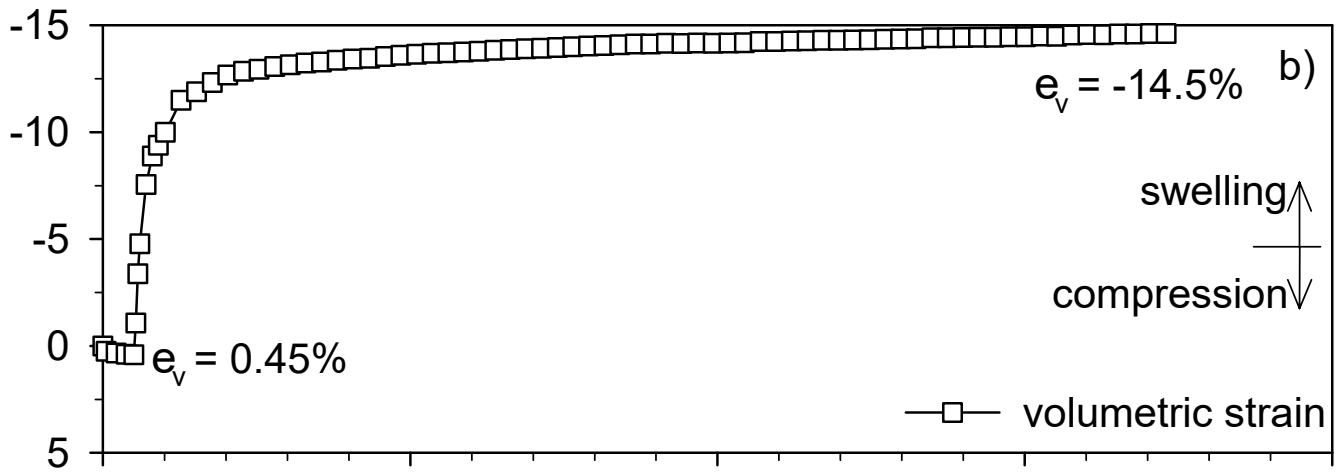

$\sum^{\pi}$
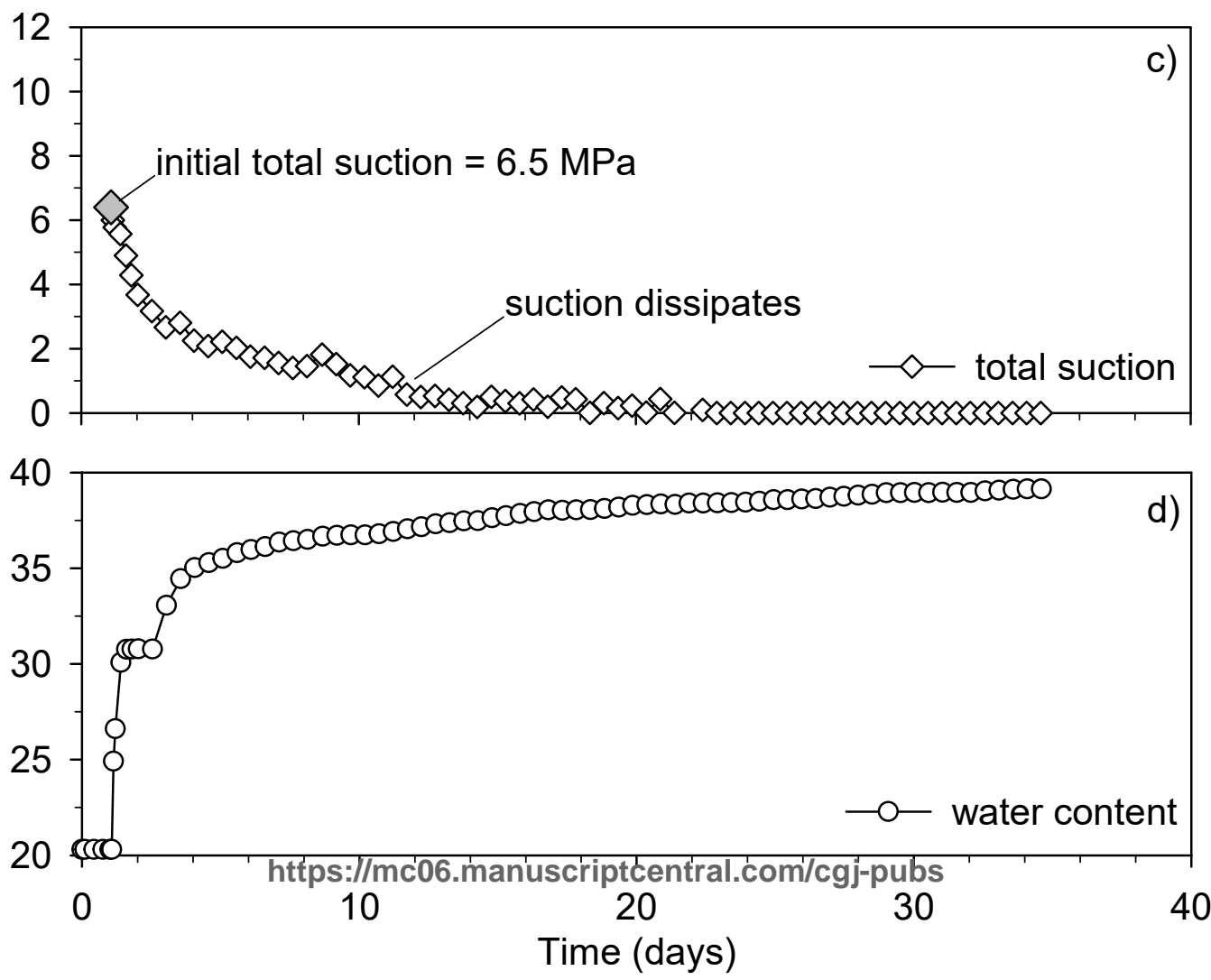
Canadian Geotechnical Journal

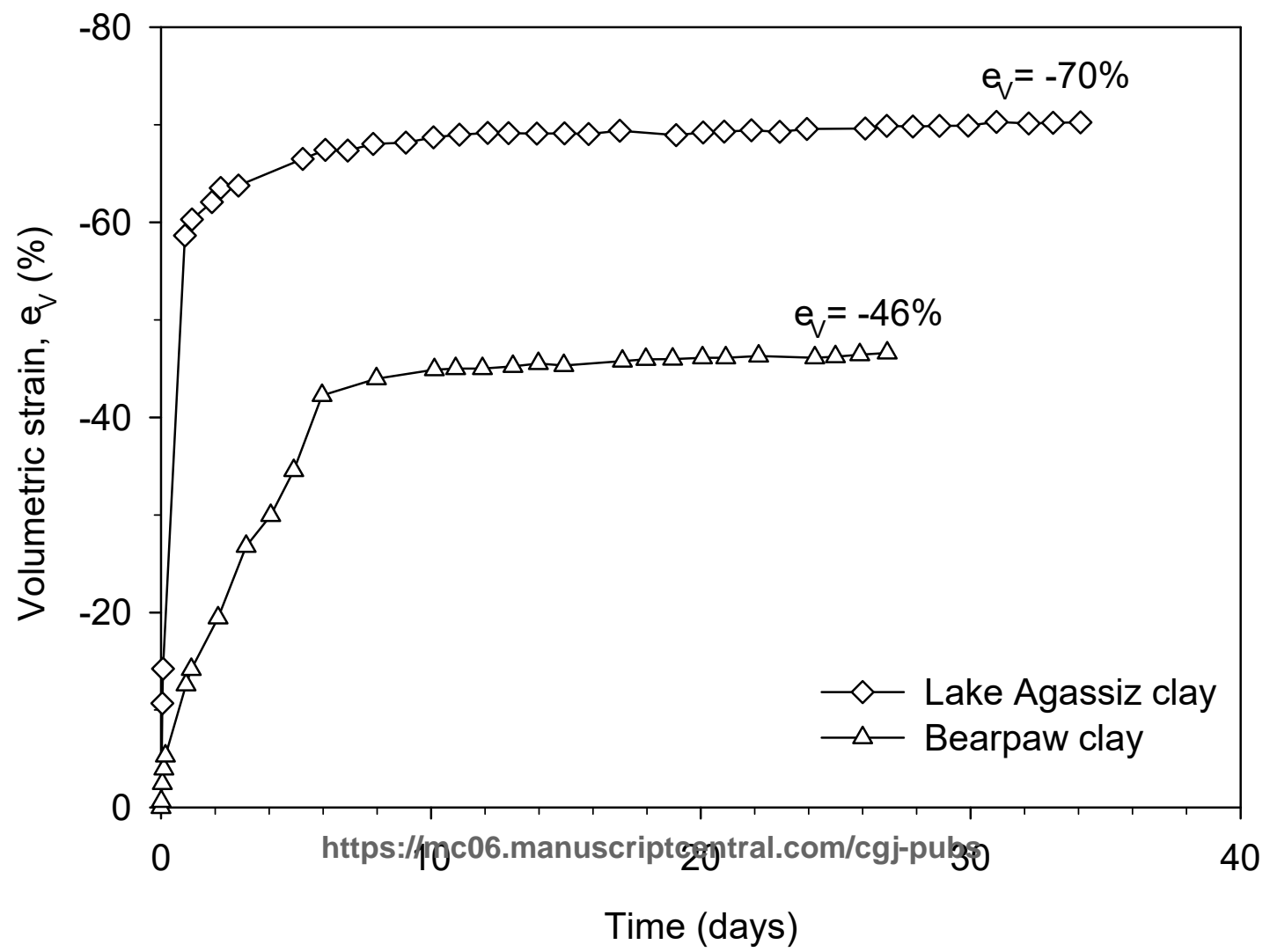




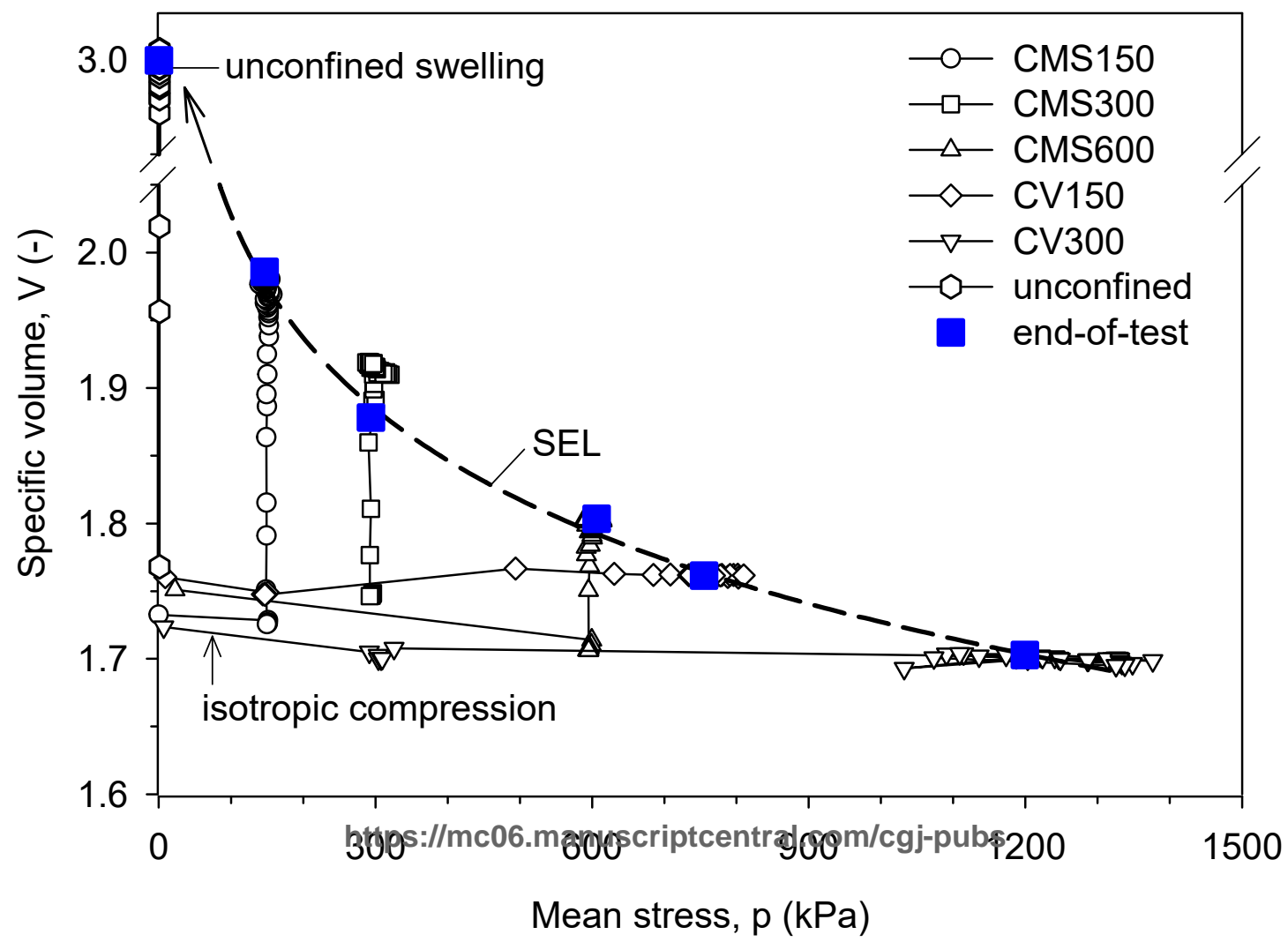



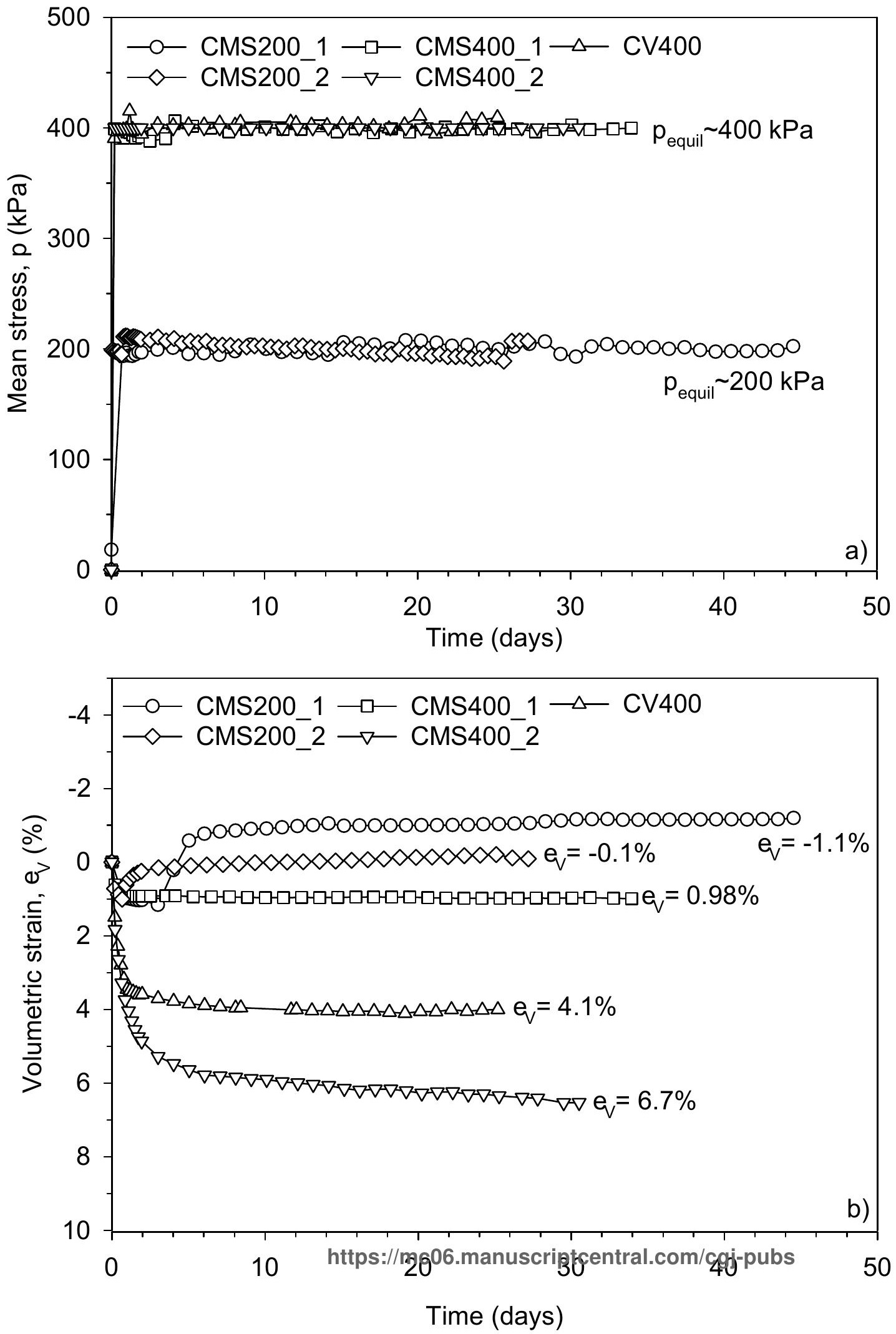

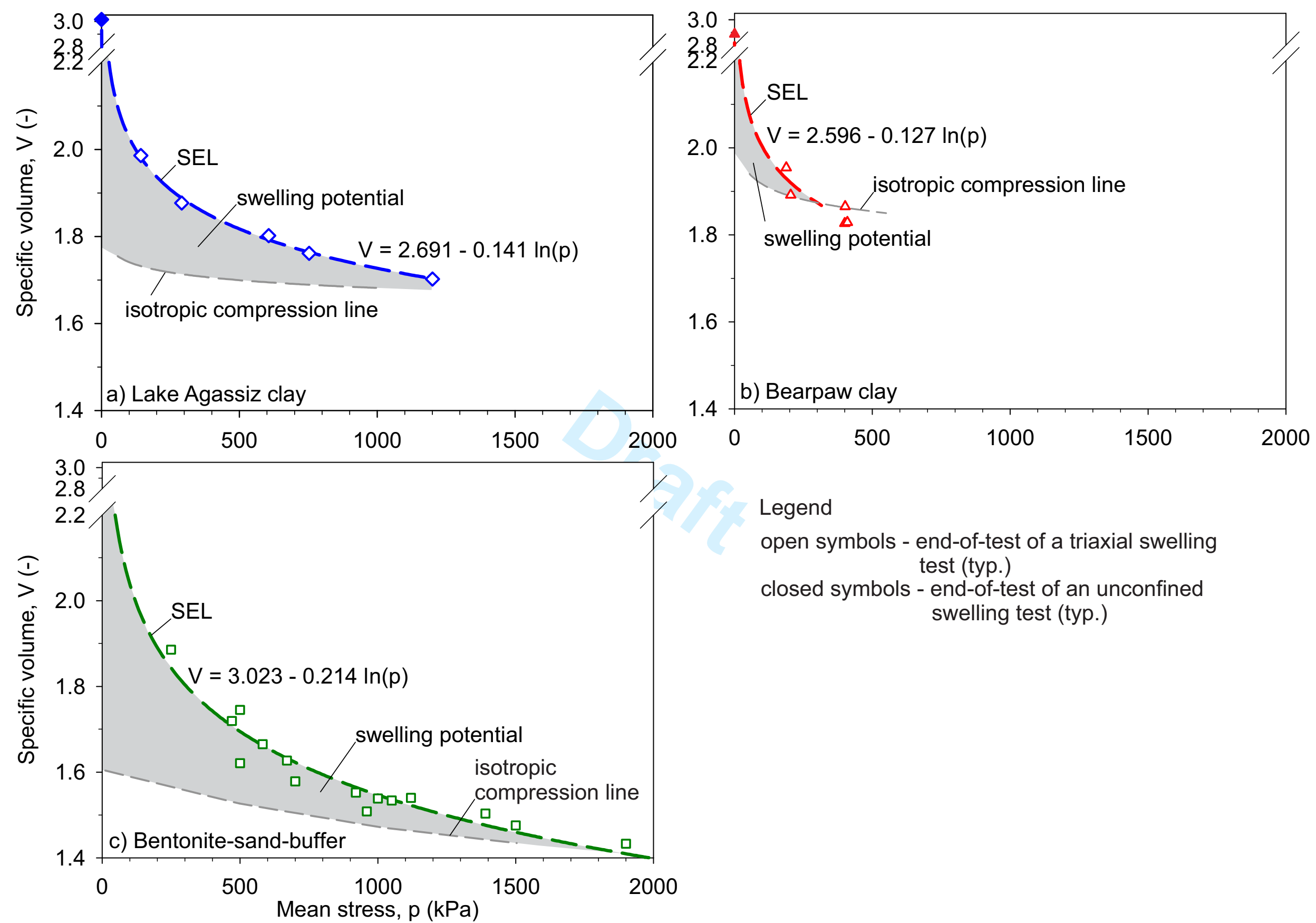

\section{Legend}

open symbols - end-of-test of a triaxial swelling test (typ.)

closed symbols - end-of-test of an unconfined swelling test (typ.)

Figure 10. Swell equilibrium Limits (SELs) for: a) Lake Agassiz clay, b) Bearpaw clay and c) Bentonite-sand-buffer (BSB). https://mc06.manuscriptcentral.com/cgj-pubs 


\section{Canadian Geotechnical Journal}

Page 42 of 45

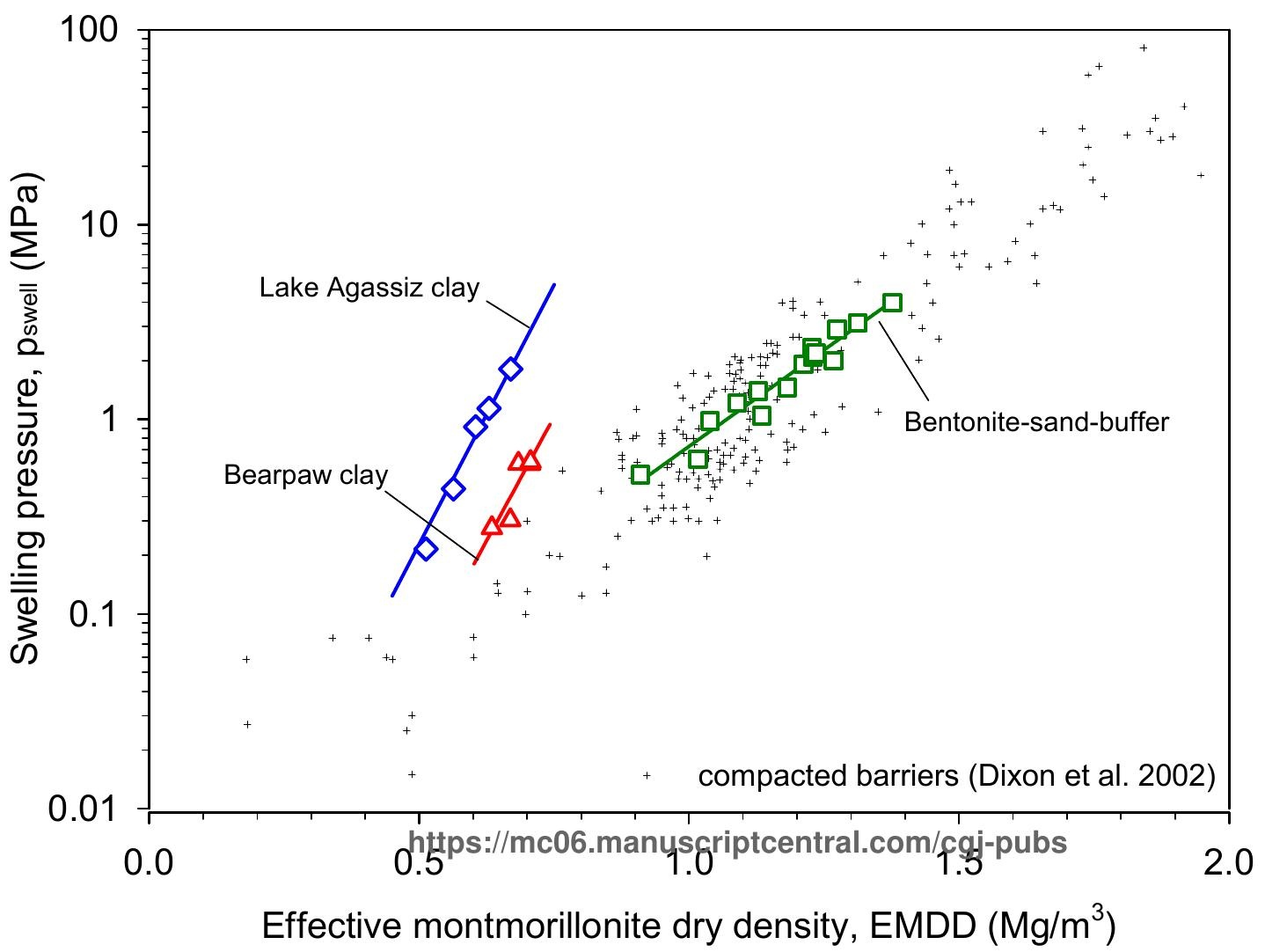



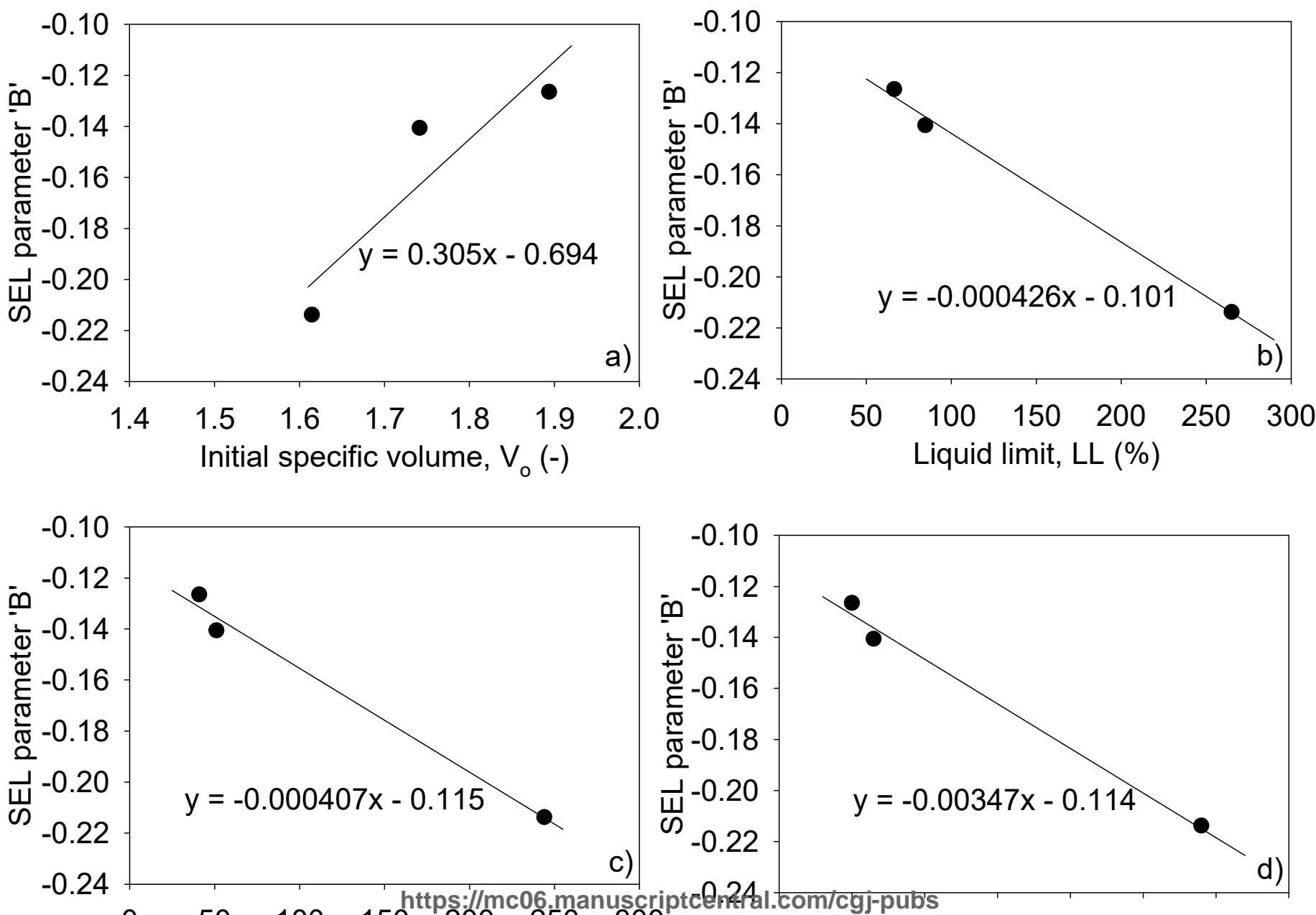

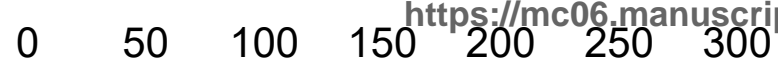
Plasticity index, PI (\%)

0

5

10

Free swell $(\mathrm{mL} / 2 \mathrm{~g})$ 


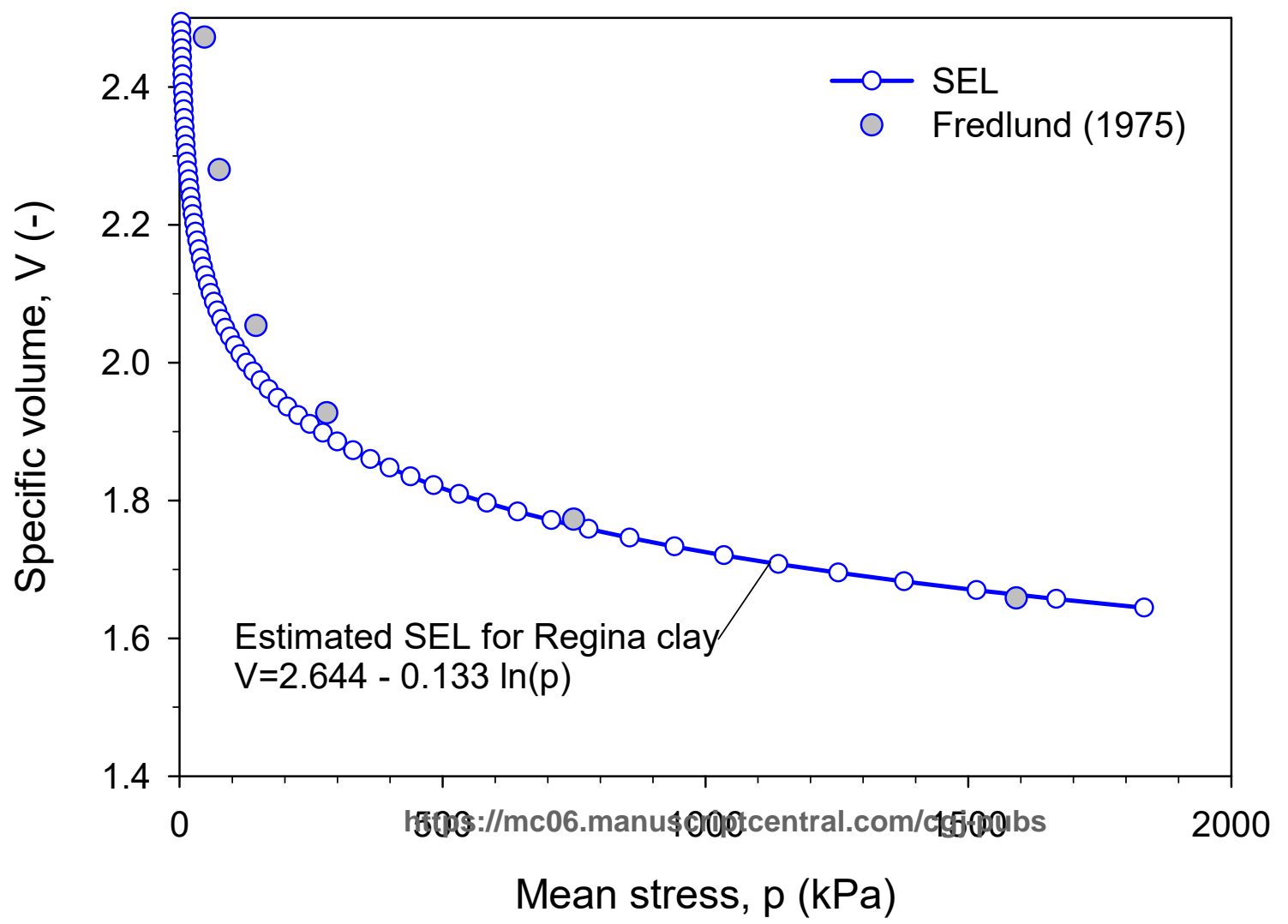

